\title{
The W-Shaped Mortality-Age Distribution of Novel H1N1 Influenza Virus Helps Reconstruct the Second Wave of Pandemic 1918 Spanish Flu
}

\section{Lai $\mathrm{KY}^{1 *}$, NG WYG ${ }^{2}$ and Cheng FF $^{3}$}

${ }^{1}$ Chief-of-service, Department of Intensive Care Queen Elizabeth Hospital, B6, 30 Gascoigne Rd. Kowloon, Hong Kong SAR, China

${ }^{2}$ Associate Consultant, Department of Intensive Care Queen Elizabeth Hospital, Hong Kong SAR, China

${ }^{3}$ Consultant, Department of Medicine, Queen Elizabeth Hospital, Hong Kong SAR, China

\begin{abstract}
Interferon is essential in human defense against influenza virus. The non-structural gene segment (NS) of influenza virus has a critical role in counteracting human interferon-mediated antiviral responses. The second wave of $1918 \mathrm{H} 1 \mathrm{~N} 1$ Spanish influenza pandemic was characterized by an enhanced mortality and a W-shaped mortality age distribution. In contrast to the U-shaped mortality-age distribution that targeted the very young and elderly during the first wave, young adult population were also affected during the second wave. The NS of the 1918 H1N1 Spanish influenza virus (1918PV) isolated during the second wave contributes to the virulence of 1918PV. This unique NS of $1918 \mathrm{PV}$ is able to inhibit human interferon production at both the pre-transcriptional and post-transcriptional level and induce cytokine dysregulation. The NS of 1918PV has entered the swine population in 1918 and re-emerged in the 2009 novel H1N1 influenza A pandemic virus (2009PV). Both seasonal and pandemic novel H1N1 influenza A viruses produced a W-shaped mortality age distribution. Information from the 2009 novel H1N1 Influenza A pandemic may help to reconstruct the mysterious surge in mortality during the second wave in the 1918 H1N1 Spanish influenza A pandemic. The W-shaped mortality-age distribution of 2009PV indicates the importance of a universal influenza vaccination policy for public protection. The high incidence of cytokine dysregulation and Streptococcus pneumoniae co-infection in hospitalized patients reflects the importance of pneumococcal vaccination and the development of immunomodulating agents that can control influenza-induced cytokine dysregulation.
\end{abstract}

\section{Introduction}

In 2009, 2009PV emerged in Mexico from swine population causing widespread human infection characterized by cytokine dysregulation and acute critical respiratory illness in young and relatively healthy individuals [1,2]. The high demand for extracorporeal membrane oxygenation (ECMO) therapy in these young critically ill patients made ECMO therapy an important consideration in future pandemic planning [3,4]. Novel H1N1 influenza pandemic has a W-shaped mortality-age distribution during the first wave $[5,6]$. The Centers for Disease Control and Prevention estimated that $77 \%$ of the novel H1N1 influenza related deaths in the United States were between 18 and 65 years of age during the first wave [7]. In 2010, the Advisory Committee on Immunization Practices (ACIP) first recommended annual influenza vaccination for all persons aged $\geq 6$ months in the United States [8]. In spite of the universal vaccination policy for seasonal influenza [9], more than $60 \%$ of hospitalizations and death for laboratory-confirmed influenza during 2013-14 influenza seasons in the United States occurred among persons aged 18-64 years, and the majority is attributed to 2009PV. No significant antigenic changes in circulating 2009PV strains compared with vaccine strains have been detected since 2009. Bacterial co-infection especially with Streptococcus pneumoniae, Streptococcus pyogenes, or Staphylococcus aureus has been reported in critically ill patients $[10,11]$. This observed W-shaped mortality-age distribution of the 2009PV infection may help to reconstruct the event in the $1918 \mathrm{H} 1 \mathrm{~N} 1$ Spanish influenza pandemic and demonstrate the need for the consolidation of current universal influenza vaccination policy in the United States for public safety. The high level of Streptococcus pneumoniae co-infection in these young individuals reflects the value of current pneumococcal vaccination program among individual aged 18 to 64 years who are at risk of pneumococcal disease. The high incidence of cytokine dysregulation in these hospitalized patients indicates further medical research should be directed towards the development of immunomodulating agents that can selectively suppress detrimental influenza-induced cytokine dysregulation without hindering protective anti-viral response of the host.

\section{The Deadly Second Wave of 1918 H1N1 Spanish Influenza A Pandemic}

Since the inception of historical records in the sixteenth century, cycles of pandemic and seasonal influenza had resulted in significant human morbidity and mortality [12]. In the last century, human pandemic influenza viruses namely 1918 H1N1 "Spanish" (1918PV), 1957 H2N2 "Asian" (H2N2PV), and 1968 H3N2 "Hong Kong" (H3N2PV) killed 40 million, 2 million, and 1 million people, respectively [13]. Pandemics can present in waves with peaks typically lasting several months associated with a greater number of cases and increased in mortality separated by troughs during which the number of cases is greatly diminished. During each wave the new influenza subtype undergo adaptation to human host or reassortment with other influenza viruses. The pandemic virus can sometimes re-emerge in a more pathological forms resulting in increased mortality in future waves [14]. In 1918, 1918PV emerged with the ability to spread among humans. The first wave of the 1918 H1N1 Spanish influenza pandemic had a mortality comparable to the usual seasonal influenza with a $\mathrm{U}$-shaped mortality-age distribution that involved the very young and elderly. However, the second wave of the 1918 H1N1 Spanish influenza pandemic had a dramatic surge in mortality and a W-shaped mortalityage distribution that involved young adults with a distinct peak of death in individuals between 20 and 40 years of age [15] (Figure 1).

*Corresponding author: LAI Kang Yiu, Chief-of-service, Department of Intensive Care Queen Elizabeth Hospital, B6, 30 Gascoigne Rd. Kowloon, Hong Kong, Tel: 852-35066363/35067309; Fax: 852-23881231; E-mail: laiky@ha.org.hk

Received October 25, 2014; Accepted March 03, 2015; Published March 06 2015

Citation: Lai KY, Ng WYG, Cheng FF (2015)The W-Shaped Mortality-Age Distribution of Novel H1N1 Influenza Virus Helps Reconstruct the Second Wave of Pandemic 1918 Spanish Flu. J Pulm Respir Med 5: 245. doi: 10.4172/2161-105X.1000245

Copyright: @ 2015 Lai KY, et al. This is an open-access article distributed under the terms of the Creative Commons Attribution License, which permits unrestricted use, distribution, and reproduction in any medium, provided the original author and source are credited. 
Type I alpha/beta interferons (IFN- $\alpha / \beta)$, encoded by a single interferon-beta (IFN- $\beta$ ) and 13 homologous interferon-alpha (IFN- $\alpha$ ) genes in humans, represent an essential element of host defense against influenza virus infection. IFN- $\beta$ plays an important role in the defense against influenza A virus that cannot be compensated for by IFN- $\alpha[16,17]$. The non-structural protein 1 (NS1) encoded by the NS of influenza virus is critical in counteracting the interferon-mediated antiviral responses of the host [18]. Wilson Smith, Christopher Andrews, and Patrick Laidrow first isolated human influenza virus in 1933 [19]. However, it was not until 1997 that the genome of the 1918 H1N1 Spanish influenza virus was isolated from archived samples of the 1918 H1N1 Spanish influenza pandemic's second wave [20]. Analysis of individual gene segments showed that the NS contributed to the virulence of the 1918PV [21-23]. The virulence of 1918PV was related to the ability of its NS to disrupt the innate immune response, induce potent cytokine dysregulation, and block the transcription of certain lipid-based proinflammatory mediators that function as part of the host antiviral response $[24,25]$. NS1 protein encoded by the NS gene of 1918PV can inhibit human inducible pre-transcriptional IFN- $\beta$ production [26] and post-transcriptional maturation and nuclear export of host interferon-related mRNAs (IFN- $\alpha / \beta$ ) via optimal binding to human $30-\mathrm{kDa}$ subunit of cleavage and polyadenylation specificity factor (CPSF30) [18,27]. The intense innate immune suppression led to an enhanced viral replication, increased viral load and cytokine dysregulation with early and excessive infiltration of macrophages and neutrophils in the lungs in 1918PV infection [28-31]. 1918PV infection was uniformly lethal in mice at low doses and produced severe lung pathology. In ferrets, 1918PV caused severe clinical disease and lung pathology with necrotizing bronchiolitis and alveolitis [32].

The H1N1 influenza virus circulated in humans from 1918 to 1957. During this period, there was substantial antigenic drift of H1N1 influenza virus from the original 1918PV strain. The H1N1 influenza virus with the same antigenic strain of the 1950s re-emerged in 1977 as seasonal H1N1 influenza virus with the usual characteristics of a low mortality and U-shaped mortality-age distribution. The NS of H1N1 viruses in 1940-1957 and 1977-1990 had lost the ability to suppress pre-transcriptional IFN- $\beta$ production [26]. The seasonal H1N1 virus emerged after 1977 caused little disease in mice and ferret model [32].

\section{The W-shaped Mortality-age Distribution of 2009 Novel H1N1 Influenza A Pandemic}

Although the NS contributes to the virulence of 1918PV, whether it can induce the $\mathrm{W}$-shaped mortality age distribution of the second wave of 1918 H1N1 Spanish influenza pandemic remains unresolved in the absence of human data. New information gained from the 2009 novel H1N1 pandemic may help to reconstruct the probable event in 1918 H1N1 Spanish influenza pandemic. 1918PV entered the swine population in 1918. The early classical swine H1N1 influenza virus caused severe clinical disease and lung pathology with necrotizing bronchiolitis and alveolitis in ferrets and mice similar to the 1918PV [32]. The NS of the 1918PV that had entered the swine population in 1918 re-emerged in the 2009PV [33]. 2009PV causes severe pathological lesions in the lungs while human seasonal H1N1 virus usually infected cells of the upper respiratory tract system. The assessment of human sera from different age groups suggests that infection with human H1N1 viruses antigenically closely related to viruses circulating in 1918 confers neutralizing antibody activity to 2009PV [34].2009PV produced an enhanced mortality with a $\mathrm{W}$-shaped mortality-age distribution that involved the young population [5-7]. Although globally there were only an estimated 201,200 respiratory and 83,300 cardiovascular deaths associated with 2009PV pandemic during the first 12 months, 65\% of these influenza-related respiratory and cardiovascular deaths were between 18 and 65 years of age [35].

Adaptation in pigs had led to several changes of the NS1 protein in the 2009PV as compared with the original 1918PV. The mutations include a K217E substitution that abolished binding to host Crk/CrkL signalling adapters, and a C-terminal truncation that deleted the PDZ binding motif. Both mutations have no major effect on replication, virulence, or transmissibility of the 2009PV [36,37]. However the truncated NS of 2009PV had retained the unique capacity to suppress human pre-transcriptional IFN- $\beta$ production similar to the original 1918PV [26]. The NS1 protein of 2009PV re-emerged from the swine population has suboptimal binding to human CPSF30. Inefficient binding of the NS1 protein of 2009PV to human CPSF30 to inhibit IFN- $\alpha / \beta$ production at the post-transcriptional level may account for the suboptimal interferon antagonistic response and reduced mortality of 2009PV infection compared with the original 1918PV [27] The NS of influenza virus is able to inhibit innate and adaptive immunity [38-40]. The suppression of innate and adaptive immunity [41,42] has led to an enhanced viral replication and a delayed viral clearance and resulted in an increased viral load in 2009PV infection [43-46].

The 2009PV induced an early and sustained hyperactive pro-

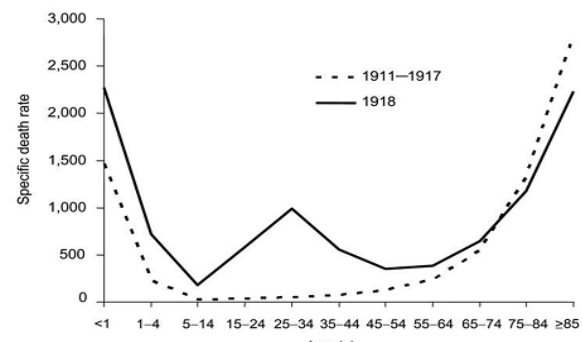

Age (y)

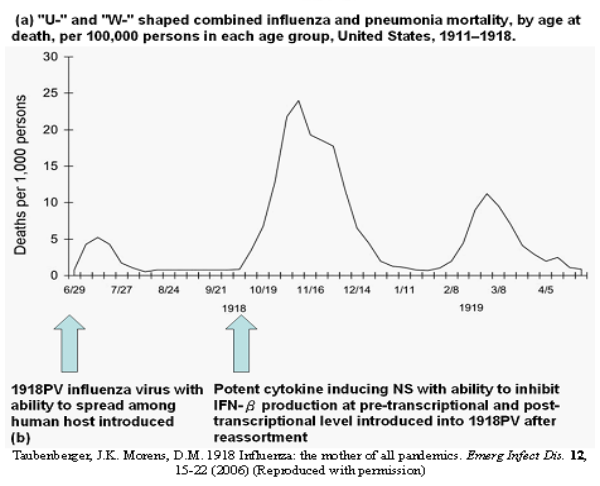

Figure 1: (a) Schematic diagram showing the W-shaped mortality-age distribution of combined influenza and pneumonia mortality of 1918 H1N1 Spanish influenza pandemic (solid line) in contrast with the U-shaped mortalityage distribution of seasonal influenza in the interpandemic years 1911-1917 (dashed line) in the United States. (b) Schematic diagram explaining the surge in mortality in the second wave of $1918 \mathrm{H} 1 \mathrm{~N} 1$ Spanish influenza pandemic: The 1918PV with ability to spread among human host was introduced in 1918 in the first wave. The first wave of 1918 H1N1 Spanish influenza pandemic had a mortality comparable to the usual seasonal influenza with a U-shaped mortality-age distribution. Reassortment of an NS with ability to suppress human innate immune response and induce potent cytokine storm through the inhibition of inducible IFN- $\triangle$ production at both the pre-transcriptional and post-transcriptional level into the 1918PV after the first wave had led to a dramatic surge in mortality and a W-shaped mortality-age distribution that involved young adults with a distinct peak of death between 20 and 40 years of age in the second wave of the $1918 \mathrm{H} 1 \mathrm{~N} 1$ Spanish influenza pandemic as shown in diagram 1a. 
inflammatory response and blocked the transcription of certain lipid-based proinflammatory mediators that function as part of the host antiviral response similar to 1918PV [47]. Adult patients with severe 2009PV pneumonia showed sustained hyper-activation of the innate pro-inflammatory cytokines (IL-6, CXCL8/IL-8, CCL2/MCP1 , and sTNFR-1), and markedly suppressed adaptive related cytokines (CXCL10/IP-10, CXCL9/MIG, and IL-17A). Patients who died five days after disease onset showed high viral load and undetectable IL-17 levels in serum. The suppression of adaptive immunity resulted in a delayed viral clearance, which in turn led to further sustained activation of the pro-inflammatory response. Elevated proinflammatory cytokines interleukin-6 (IL-6) predicted critical illness requiring ICU admission $[48,49]$. IL6 was a biomarker for severe disease in young adults below 18 years of age [50]. In children, high level of IL-6 was associated with mortality. Nonsurvivors were immunosuppressed with leukopenia and markedly reduced tumor necrosis factor- $\alpha$ (TNF- $\alpha$ ) production capacity. A TNF- $\alpha$ response of less than $250 \mathrm{pg} / \mathrm{mL}$ was highly predictive of death and longer duration of ICU stay [51].

Bacterial co-infection was associated with adverse outcomes in hospitalized adult patient with 2009PV infection [52]. 41\% of the deaths of 2009PV infection had bacterial co-infection and Streptoccoccus pneumoniae was the most common organism identified [53]. Most of the severe infection of 2009PV accompanied by pneumonia and increased mortality were between 15 and 44 years old [5,54]. Young patients in this age range and without any underlying disease had impaired immune responses for Streptococcus pneumoniae after 2009PV infection due to defective cytokine response with suppressed TNF- $\alpha$ production and alteration of adaptive immunity [55]. In contrast to previous seasonal influenza seasons, pediatric deaths related to 2009PV were less likely to have a bacterial co-infection with methicillin resistant Staphylococus aureus (MRSA). Many had bacterial co-infections with Streptococcus pneumoniae, as has been found in other studies [56,57].

\section{Pathogenesis of the W-shaped Mortality Distribution} of 1918 Spanish Influenza Pandemic and 2009 Novel H1N1 Pandemic: The Interplay of A Potent Innate Immune Suppressing NS, Heavy Viral Load, Cytokine Dysregulation and Bacterial Co-infection

Seasonal and pandemic influenza are an important cause of morbidity and mortality among the very young and elderly in both healthy population and in patients with chronic medical conditions and altered immune response [58]. $\mathrm{H} 2 \mathrm{~N} 2$ and $\mathrm{H} 3 \mathrm{~N} 2$ pandemics and seasonal influenza epidemics in the past century had a U-shaped mortality curves with most of the influenza-related deaths being the result of the exacerbation of an underlying condition or secondary to bacterial co-infections among the very young and the elderly [59]. The synergistic role of bacterial co-infection in enhancing the mortality of influenza infection has been known and documented for nearly a century [60]. Individual at the extremes of ages are more susceptible to bacterial co-infection after influenza infection due to bacterial colonization, immune dysfunction and co-morbidities [61,62]. The human upper respiratory tract of infants and children is the reservoir of a diverse community of potential pathogens such as Streptococcus pneumonia, Haemophilus influenza and Staphylococus aureus [63-65] which predispose these young individuals to invasive disease after an influenza infections [66-69]. Oral colonization by respiratory pathogens [70-73] and changes in pulmonary reserve, decreased mucociliary transport, decreased cough reflex, decreased elasticity of alveoli and poorer ventilation-all of which lead to diminished cough and airway patency - cause older adults to be more susceptible to bacterial pneumonia, especially after an influenza infection [74]. It has been estimated that persons who are 65 years and older account for more than $80 \%$ of all pneumonia- and influenza-related deaths. Most of the excess mortality caused by influenza and/or pneumonia is attributed to elderly with high-risk conditions [75]. Influenza increases clinical pneumococcal disease incidence in elderly patients. An additive effect was observed in reducing the need for hospital admission for influenza and pneumonia [76] and the prevention of all-cause mortality with influenza and pneumococcal vaccines given together in elderly people, including in those with underlying chronic disease [77]. Hence apart from underlying co-morbidities, bacterial co-infection has a major contribution to the enhanced mortality in the extremes of age and the U-shaped mortality age distribution during influenza seasons [78].

In the United States between 1911 to 1918 , curves of influenza mortality by age at death are typically $U$-shaped, reflecting high mortality in the very young and elderly with low mortality at all ages in between [15]. The 1918 to 1919 pandemic and succeeding winter epidemic recurrences in 1919 and 1920 instead produced a W-shaped mortality curves, which featured a third mortality peak in healthy young adults between 20 to 40 years of age that accounted for approximately half of the total influenza deaths, including the majority of excess influenza deaths. Perhaps the most puzzling mystery of the 1918 pandemic is how to explain that extraordinary excess influenza mortality in persons between 20 to 40 years of age which was responsible for the $\mathrm{W}$-shaped mortality age distribution during the pandemic. Although animal studies using the 1918PV regenerated from archived samples collected from patients who succumbed during the 1918 H1N1 Spanish influenza pandemic's second wave suggested the important role of cytokine dysregulation in the pathogenesis, historical data and autopsy series indicate that almost all deaths resulted from secondary bacterial bronchopneumonia and that frank acute respiratory distress (ARDS)like syndromes in the absence of bacterial pneumonia, and thus, conceivably attributable to primary viral pneumonia and/or cytokine storms, have been uncommon causes of death. Many of these patients have acute aggressive bronchopneumonia featuring tracheobronchial epithelial necrosis [79]. The major bacteria identified in the pandemic were Streptococcus pneumoniae, Streptococcus pyogenes, and, less commonly, Staphylococcus aureus and Haemophilus influenza [80].

An intact interferon response plays an important role in determining the pathogenicity, tissue restriction and systemic dissemination of influenza infection. Mice that are unable to mount an interferon response due to disruption of the STAT1 gene are 100fold more sensitive to lethal infection with influenza virus and develop fulminant systemic disease after influenza virus infection $[81,82]$. The NS1 protein encoded by the NS of influenza virus plays a critical role in inhibiting interferon-mediated antiviral responses. Influenza A virus lacking the NS1 protein encoding gene can only replicate in interferondeficient systems $[83,84]$. Influenza A and B virus mutants containing a NS with "weak" anti-interferon activity are highly attenuated [85-88]. There is one single IFN- $\beta$ and 13 homologous IFN- $\alpha$ genes in humans. IFN- $\beta$ plays an important role in the defense against influenza A virus that cannot be compensated for by IFN- $\alpha$. The unique NS of 1918PV is able to inhibit interferon production at both pre-transcriptional [26] and post-transcriptional level [18,27]. In contrast to other human influenza viruses in the last century, the NS1 protein of the 1918PV and 2009PV binds to retinoid-inducible gene 1 (RIG-I) to inhibit the downstream activation of interferon regulatory factor 3 (IRF3) and the subsequent production of IFN- $\beta$ at the pre-transcriptional level [26,89-92]. In common with the other human influenza in the last century, the NS1 protein of $1918 \mathrm{PV}$ inhibit type I interferon (IFN- $\alpha / \beta)$ 
production at the post-transcriptional level through optimal binding of the C-terminal effector domain to CPSF30. Subsequently, newly synthesized host cellular mRNAs including interferon and interferonstimulated genes are unable to export from the nucleus after infection due to inhibition of 3' cleavage and polyadenylation. This results in the establishment of an influenza virus-specific translational system that selectively translates viral and not host mRNAs [18,27,93-96]. The intense innate suppression conferred by the NS allows 1918PV to replicate at a rate over 200 fold than that of seasonal H1N1 [31]. This allowed 1918PV to replicate swiftly at the "stealth phase" and attain high steady-state titers in the lungs within 48 hours after infection to induce direct cytopathic damages and cytokine dysregulation [97]. The NS mediated delay of interferon induction contributed to the virulence of 1918PV by influencing the spread to and replication efficiency of 1918PV in the lower respiratory tract [24]. 2009PV also demonstrated an enhanced replication in the lower respiratory tract and led to virusassociated diffuse alveolar damage in nonhuman primate model $[34,98]$. A comparison of the pathology of 1918PV 2009PV and seasonal H3N2 virus infection showed that $1918 \mathrm{PV}$ and $2009 \mathrm{PV}$ infect the mucosal epithelial cells of the airways, alveolar macrophages, and pneumocytes, whereas seasonal influenza H3N2 mainly infects mucosal epithelial cells of the larger airways [99]. The above evidences underlies the important role of an innate immune response suppressing NS in the production of severe pneumonia in the host through enhanced tropism of 1918PV to tissue of the lower respiratory tract and an increased viral load which is pivotal to cytokine dysregulation, pulmonary damage and mortality in influenza infection [100-102]. 1918PV showed an enhanced virulence in non-human primate $[103,104]$. The pathogenicity of the NS of $1918 \mathrm{PV}$ to human cell is species specific. The species specificity of NS was first discovered during testing of the individual gene segments of the 1918PV in mice. The NS gene that is virulent to human cells [2123 ] is less virulent than the corresponding wild-type control virus in mice [105]. 2009PV which induces a potent cytokine dysregulation and produces an enhanced mortality and a mortality-age distribution that involved young adults in humans, only causes modest disease in ferrets [105],[106] and asymptomatic infection in pathogen free miniature pigs [34]. The asymptomatic infection of 2009PV in pathogen free miniature pig explains why there was no detectable outbreak of 2009PV infection in the swine population before the virus surfaced in humans.

Early cytokine dysregulation is a common feature in 1918PV $[30,107]$ and 2009PV $[48,49,108,109]$ infection. As a major transcription factor for antiviral and immune stimulatory activities, nuclear factor kappa-B (NF- $\kappa \mathrm{B})$ play an important role in the induction of interferon and other pro-inflammatory molecules such as IL-6 upon cellular responses against a virus infection $[110,111]$. Influenza A virus, being a small RNA virus with relatively small coding capacity and protected by the anti-interferon activity of its NS, has taken advantage of the host NFKB activation pathway [112] to enhance the synthesis of viral ribonucleic acid [113] and nuclear export of viral ribonucleoprotein (vRNP) complexes [114] and during the process leads to apoptosis of the host cell [115-117] and induces cytokine dysregulation [118,119]. The cytopathic damage and cytokine dysregulation result in an enhanced morbidity and mortality [120]. Either mechanism of tissue damage may predominate in individual patient [121]. NFkB activation is a prerequisite for influenza infection [122] and influenza-induced cytokine dysregulation $[118,119,123,124]$. The lack of hypercytokinemia in NF- $\kappa \mathrm{B}$-deficient mice during influenza infection confirms the central role of NF- $\mathrm{KB}$ in cytokine dysregulation [118]. Immune suppression conferred by the NS lead to an enhanced viral replication and an increased in viral load in 1918PV [28,29,31] and 2009PV [4346] infection. The accumulation of endosomal haemagglutinin (HA)
[125] and viral dsRNA [126] during an enhanced viral replication may in turn, activate NFKB to induce cytokine dysregulation $[119,123,126]$ ROS acts as the second messenger in inducers of influenza-induced NF- $\kappa B$ activation [119,127-129]. HA activates NFKB through the production of reactive oxygen species via endoplasmic reticulum overload (ER-overload) [127,130-133]. Toll-like receptor 3 (TLR3) is expressed both intracellularly and on the cell surface of respiratory epithelial cells [134]. Influenza dsRNA inside the endosome activates NF-kB through upregulation of the TLR3 expression [135,136]. Stable influenza dsRNA released from dying influenza virus-infected cells [137] binds to TLR3 on the epithelial cell surface to activate NF-kB [138]. ROS enhances TLR3 induced NFKB activation in reaction to viral dsRNA in airway epithelial cells [139]. Apart from the activation of NF- $\kappa B$ via the TLR3 signal pathway, dsRNA is able to active NLRP3 inflammasome signal pathway. dsRNA can elicit an enhanced antigen-specific Th1-polarized immune response and dampened Th17 response [140], a feature of the cytokine dysregulation of 2009PV infection [49]. NF-кB-induced IL-6-STAT3 signaling pathway is an important pro-inflammatory response after influenza A infection [141]. Level of IL-6 correlated with the magnitude of influenza virus replication and cell damage in human tracheal epithelium [142] and is a prognostic biomarkers for progression to respiratory failure and mortality in influenza A infection [48-50,143]. Anti-oxidants are able to suppress NFאB-induced IL- 6 production in influenza infection [144-146]. Inflammasome activation is important in the development of both innate [147] and adaptive immune responses [148,149] during influenza infection. An intact body commensal microbiota regulates immune defense against respiratory tract influenza $A$ virus infection by priming basal levels of pro-IL-1 $\beta$ and pro-IL-18 at steady state.[150]. Influenza viruses activate inflammasome to induce interleukin- $1 \beta$ (IL$1 \beta$ ) and interleukin-18 (IL-18) production [151-153] through M2 protein expression [154] under the regulation of the $\mathrm{N}$-terminal region of the NS1 protein that does not involved in RNA-binding activity [155158]. On the other hand, the N-terminal RNA-binding domain of the NS1 protein restricts the production of the mature form of IL- $1 \beta$ and IL-18 through the inhibition of caspase-1-dependent post-translational processing of pro-IL- $1 \beta$ and pro-IL-18 to repress PKR-dependent apoptosis [159]. In spite of the suppression by the $\mathrm{N}$-terminal RNAbinding domain of the NS1 protein, active IL- $1 \beta$ is secreted into bronchoalveolar lavage of mice infected with influenza virus in a dose-dependent manner through the caspase-1 dependent pathway [160-164]. 1918PV up-regulates inflammasome early after infection and produces early cytopathic damage of the respiratory epithelium and cytokine dysregulation [104]. Both IL6 and IL-1 $\beta$ are up-regulated in 2009PV infection. IL-6 was significantly correlated with specific clinical findings, such as severity of respiratory compromise and fever. No correlation was found between IL- $1 \beta$ expression and final outcome [165]. HA [166] and dsRNA [167-169] can also induce IL- $1 \beta$ and IL-18 through NLRP3 inflammasome activation. The M2 protein, HA and dsRNA accumulated during rapid viral replication may account for induction of IL- $1 \beta$ and IL-18 level during 1918PV because the 1918PV has been found to have a replication rate that is greater than 200 -fold of seasonal H1N1 virus [31]. NLRP3 inflammasome activation in influenza infection is ROS dependent [[170-172]. Influenza induced M2-dependent IL-1 $\beta$ production can be inhibited by anti-oxidants [173].The hypersecretion of IL-18 induced by inflammasome activation may lead to the development of acute respiratory distress syndrome [174], multiple organ failure [175] and haemophagocytic syndrome $[176,177]$. Pathological evidence of haemophagocytic syndrome was a common finding in patient died of 1918PV infection [176]. 2009PVinduced haemophagocytic syndrome [179-182] is a major contribution to mortality in human 2009PV infection [183]. 
1918PV and 2009PV have an enhanced tropism to cells of the lower respiratory tract. Severe tracheobronchial/alveolar epithelial necrosis was a prominent feature in patients died of 1918PV infection. 1918PV, protected from the anti-interferon activities by its NS, produce a heavy viralload and induce cytokine dysregulation in humans. The accumulated $\mathrm{HA}$ and dsDNA resulting from an enhanced viral replication induce caspase 3-dependent apoptosis of the tracheobronchial tree through the NF- $\kappa B-I L-6$ activation pathway. 1918PV up-regulates inflammasome early after infection and produces severe apoptosis of the respiratory epithelium as early as 12 hours after infection [104]. Hence, heavy viral load, IL6 hypersecretion, early inflammasome activation and enhanced tissue tropism to cells of the lower respiratory tract due to the presence of a potent innate immune suppressing NS may contribute to the severe mucosal damage of 1918PV infection. The NS-induced adaptive innate immune suppression predisposed these patients with severe tracheobronchial epithelial necrosis to bacterial co-infection, in particular Streptococcus pneumoniae. Upon introduction of 1918PV into humans in 1918, exceptionally high mortality was seen during the first 2 years that this subtype circulated, primarily due to bacterial pneumonia. Thereafter, the overall mortality rate declined, but excess mortality continued to be seen. H1N1 viruses reentered the population in 1976 as seasonal H1N1. The NS of seasonal H1N1 viruses had lost the ability to suppress pre-transcriptional IFN- $\beta$ production [26] and induce necrotizing bronchiolitis and alveolitis [28] as the original 1918PV. Very little excess mortality has occurred during years where seasonal $\mathrm{H} 1 \mathrm{~N} 1$ viruses were the predominant circulating strain, and the relative contribution of bacterial superinfections to excess mortality has declined [184]. The NS of 1918PV entered the swine population in 1918 and emerged in 2009PV [29]. The NS of 2009PV has retained the ability suppress pre-transcriptional IFN- $\beta$ production [26] and induce cytokine dysregulation as the original 1918PV [29,185]. Severe tracheitis, necrotizing bronchiolitis, alveolitis and haemophagocytic syndrome are common post-mortem finding in patient with fatal 2009PV infection [186,187]. 2009PV have altered the epidemiology of invasive pneumococcal disease and shifted the age distribution to healthy young adults $20-39$ years of age, the age group that has a distinct peak of death in 1918 Spanish Influenza pandemic and contributed to the $\mathrm{W}$-shaped mortality age distribution of the 1918PV. A high proportion of hospital admission during the first wave of 2009 novel H1N1 influenza pandemic due to invasive pneumococcal disease among 20-39 years of age required admission to intensive care unit. 2009PV has also led to invasive pneumococcal disease among persons 18-64 years of age with an increased prevalence of underlying conditions [188].With this new information from 1918PV and 2009PV, we may be able to reconstruct the probable events in the $1918 \mathrm{H} 1 \mathrm{~N} 1$ Spanish influenza pandemic.

\section{Reconstruction of the 1918 H1N1 Spanish Influenza Pandemic}

1918PV which killed 40 million people worldwide was characterized by an enhanced mortality and a W-shaped mortality age distribution during the second wave in contrast to the $\mathrm{U}$-shaped mortality-age distribution of pandemic $\mathrm{H} 2 \mathrm{~N} 2$ and $\mathrm{H} 3 \mathrm{~N} 2$ and epidemic seasonal influenza in the last decades. Most of these people who succumbed to $1918 \mathrm{PV}$ infection had pathological evidence of extensive mucosal damage of the tracheobronchial/alveolar tree and secondary bacterial co-infection. The unique NS of the 1918PV of the second wave is able to block interferon production at both pretranscriptional and post-transcriptional level and induce cytokine dysregulation. We hypothesized that $1918 \mathrm{PV}$ with the ability to spread among human host was introduced in 1918 in the first wave. The first wave of 1918 H1N1 Spanish influenza pandemic had a mortality comparable to the usual seasonal influenza with a U-shaped mortalityage distribution. Reassortment of an NS with ability to induce potent cytokine dysregulation and suppress human innate immune response at both the pre-transcriptional and post-transcriptional level into the $1918 \mathrm{PV}$ after the first wave led to an enhanced viral replication and viral tropism to tissue of the lower respiratory tract. The enhanced viral replication and the subsequent heavy viral load led to an endosomal accumulation of HA and dsDNA which in turn, activate the NFkBIL6 and inflammasome signaling pathway via the production of ROS through ER-overload. ROS also enhances TLR3 induced NFKB activation in reaction to viral dsRNA in endosome and in airway epithelial cells. The enhanced tropism to tissue of the lower respiratory tract, high viral load, hypersecretion of IL6 and early inflammasome activation induce extensive damage of the epithelium of the tracheobronchial tree and predisposed otherwise healthy human host to bacterial co-infection. Under the intense adaptive innate immune suppression of the NS, bacterial co-infection led to a dramatic surge in mortality in healthy young adults between 20 and 40 years of age. In couple with the usual $\mathrm{U}$-shaped mortality distribution among the very young and elderly, the enhanced mortality among young adults between 20 and 40 years of age produced a W-shaped mortality-age distribution in the second wave of the 1918 H1N1 Spanish influenza pandemic. The enhanced mortality of bacterial co-infection among the young adults persisted in the first 2 years after the introduction of this unique NS into 1918PV. This resulted in a higher mortality during the third wave compared with the first wave (Figure 1b). The hypothesis outlines the contributing role of a potent innate immune suppressing NS of influenza viruses in producing cytokine dysregulation, bacterial co-infection and an enhanced mortality. It also explains why there is no major change in histopathology of fatal influenza pneumonias between pandemic and seasonal influenza as documented over the past 120 years [189] probably because the cytopathic damage, cytokine dysregulation and enhanced mortality are resulting from an increased viral load, a reflection of the severity of the underlying influenza virus infection that finally lead to the death of the patients.

\section{Implication on the Importance of A Universal Influenza Vaccination Policy}

There is a difference in seasonal influenza vaccination recommendation between the World Health Organization (WHO) and the ACIP of the United States. WHO recommends influenza vaccination for the very young and elderly and at risk groups such as patients with chronic medical conditions, pregnant women and healthcare workers [190]. ACIP recommended annual influenza vaccination for all persons aged $\geq 6$ months in the United States since 2010 [8]. Pandemic influenza viruses containing an NS capable of suppressing inducible interferon production at either the pre-transcriptional (2009PV) $[26,27]$ or post-transcriptional level (H2N2 and H3N2) [27] produced a mortality of less than $0.1 \%$ [15,31]. The 1918PV which suppressed inducible interferon production at both the pre-transcriptional $[26,27]$ and post-transcriptional levels $[18,27]$ led to a mortality of $2.5 \%$ [15] (Figure 2). If 2009PV were to acquire the amino acid structure essential for optimal binding to human CPSF30 during transmission in humans, the virulence of seasonal novel H1N1 influenza virus may escalate [27]. The W-shaped mortality-age distribution of seasonal novel H1N1 influenza virus and its potential for increased virulence after optimal adaptation to humans underscores the importance of the consolidation of the current universal vaccination policy for all persons 6 months and older in the United States $[8,9]$. The WHO should work towards a universal vaccination policy as 


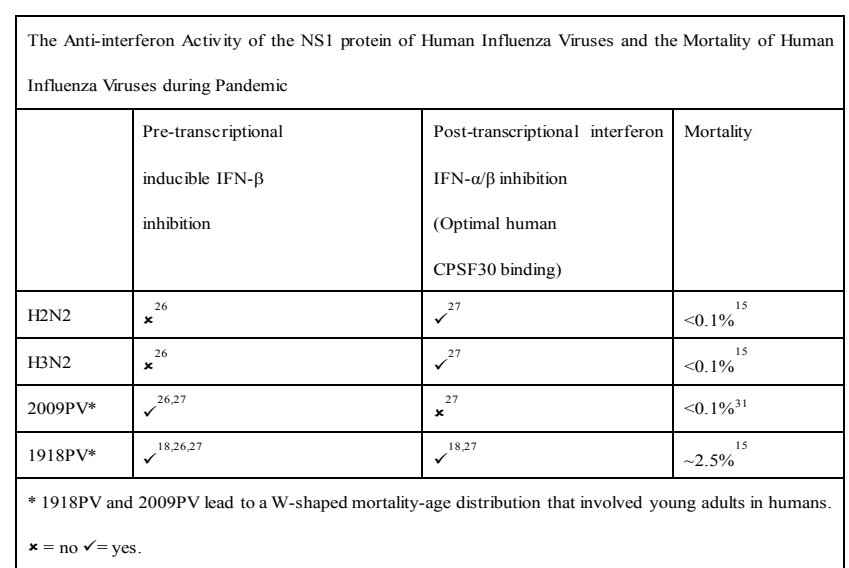

Figure 2: Table showing the anti-interferon activity of the NS1 protein of human influenza viruses and the mortality of human influenza viruses during pandemic. 1918PV and 2009PV are able to inhibit pre-transcriptional IFN- $\mathbb{Q}$ production. H2N2, H3N2 and 1918PV are able to inhibit post-transcriptional maturation and nuclear export of host interferon-related mRNAs (IFN- $\alpha / \beta$ ) via optimal binding to the human $30-\mathrm{kDa}$ subunit of cleavage and polyadenylation specificity factor (CPSF30).

recommended by ACIP for public protection. The potential increase in virulence of $\mathrm{H} 3 \mathrm{~N} 2$ after the reassortment of the NS of 2009PV during transmission in humans should be monitored.

\section{Implication on The Importance of Pneumococal Vaccination and Smoking Cessation Campaign}

Pneumococcal vaccination program for persons at an increased risk of pneumococcal pneumonia and smoking cessation campaign should be consolidated to reduce the risk of Streptococcal pneumoniae co-infection in anticipation of an enhanced virulence of novel H1N1 influenza A virus after its NS1 protein can better adapt to human CPSF30 protein and in preparation of an $\mathrm{H} 5 \mathrm{~N} 1 / \mathrm{H} 7 \mathrm{~N} 9$ avian influenza pandemic. During the influenza pandemics of 1918, 1957, and 1968, a bacterial etiology exists in as many as $50 \%$ to $95 \%$ of patients with fatal or life-threatening pneumonia. Streptococcus pneumoniae is the most common vaccine preventable organism in bacterial co-infection during these pandecmics [191-193]. Streptococcal pneumoniae coinfection is correlated with the severity of 2009PV infection [194] and was the most common organism identified in patients who died of 2009PV associated bacterial co-infection [53,195]. Streptococcus pneumoniae and influenza virus mutually potentiate the proliferation of each other through viral-bacterial synergistic interaction [196,197]. Influenza virus infection predisposes to Streptococcus pneumoniae co-infection by opening neuraminidase site for the attachment of Streptococcus pneumoniae $[198,199]$ and impairing the host defenses against Streptococcus pneumoniae [200-203]. Highly pathogenic H5 and $\mathrm{H} 7$ avian influenza viruses possess polybasic amino acid motif at the haemagglutinin (HA)-cleavage site that allows cleavage activation via proteases produced during bacterial co-infection. These bacterial proteases could activate haemagglutinin (HA) directly or indirectly through the plasminogen/plasmin system to facilitate viral replication and enhance the pathogenicity of these plasmin-sensitive avian influenza virus strains [204-207] (Figure 3). This underscores the importance of pneumococcal vaccination for persons at increased risk of pneumococcal pneumonia during pandemic situation [208-210]. Current pneumococcal vaccination program should be expanded to include healthy young adults without underlying disease in the age range 20 to 40 because they have been shown to have impairments of the immune responses for Streptococcus pneumoniae after novel H1N1 infection due to defective cytokine response and alteration of adaptive immunity [55,188]. Pneumococcal vaccination to smoker should be emphasized because cigarette smoking activates platelet-activating factor receptor that allowed attachment of Streptococcus pneumoniae to lower airway cells [211-213]. Apart from increasing chance of invasive pneumococcal disease, tobacco smoke-induced oxidant stress and suppression of innate immunity are mechanistic factors leading to increases viral replication and increases severity of respiratory disease with influenza [214-217]. Smoking is the strongest independent risk factor for invasive pneumococcal disease among immunocompetent, nonelderly adults [218]. Smoking also increase influenza-associated mortality risks among elders [219].This is of particular importance in China where tobacco smoking is highly prevalent $[220,221]$.

\section{Implication on The Importance of The Development of Immunomodulatory Therapy to Control Influenza- induced Cytokine Dysregulation}

Early cytokine dysregulation are associated with 1918PV [30], 2009PV [48,49], H5N1 [222,223] and H7N9 [224-226] infection. Annual influenza vaccination program and currently approved antiviral medications that are directed against the mutable targets of influenza viruses cannot directly prevent cytokine dysregulation. Since the adaptive cellular immunity and the associated cytokine responses are impaired/downregulated in 2009PV pneumonia, further immunosuppressive is unlikely beneficial and may even be harmful [49]. Early use of glucocorticoids was a risk factor for critical disease and death from 2009PV infection [227,228]. Steroid therapy for the treatment of cytokine dysregulation of human $\mathrm{H} 7 \mathrm{~N} 9 / \mathrm{H} 5 \mathrm{~N} 1$ avian influenza infection adds to the complications of superinfection, hyperglycaemia and the development of drug resistant mutants without improving survival [229-231]. Hence, future research on immunomodulating therapy for severe influenza infection should consider medications that can selectively suppress the host pro-inflammatory response but maintain the host anti-viral activity intact. Like all viruses, the influenza virus largely relies on host cell factors and physiological processes to induce cytokine dysregulation and death of the host. Research focused on these non-mutable key steps in the pathogenesis of influenza-induced

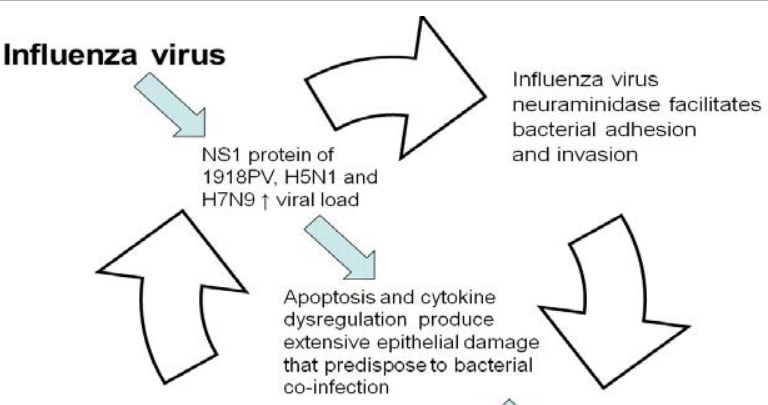

Cleavage activation of influenza haemagglutinin by bacterial proteases amplifies viral proliferatio

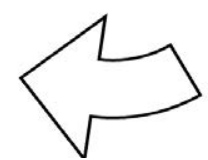

Streptococcus pneumoniae Haemophilus influenzae Staphylococcus aureus Streptococcus pyogenes

Figure 3: Schematic diagram outlining the mechanisms of viral-bacterial synergistic interaction in bacterial co-infection during influenza pneumonia: Influenza viruses open neuraminidase site for the attachment of bacteria and predispose to bacterial co-infection. Bacterial infection amplifies vira proliferation by producing extracellular proteases for cleavage activation of influenza haemagglutinin. Influenza viruses with a potent innate immune response suppressing NS (e.g. as 1918PV, H5N1 and H7N9) produce a heavy viral load and induce cytokine dysregulation. This results in extensive pulmonary epithelial damage and predisposes to secondary bacterial infection. 
cytokine dysregulation inside the host may be novel targets for future therapeutic strategies against these rapidly mutating viruses. They may also have a complementary role to those anti-viral medications and vaccines under development that are directed against the mutable targets of influenza viruses. Immunomodulatory agents that has been proposed for influenza management may include $\mathrm{N}$-acetylcysteine (NAC), macrolides, cyclooxygenase-2 inhibitors (COX-2 inhibitors), mesalazine, paracetamol, statins, peroxisome proliferator-activated receptor agonists, high dose intravenous gammaglobulin (IVIG), AMP-activated protein kinase agonists and high mobility group box 1 antagonists [232,233]. Many of these medications are approved by the Food and Drug Administration (FDA) for the treatment of other diseases. They are available and stockpileable for immediate use. They are currently produced as inexpensive generics, global supplies are huge, and they would be available to treat patients in any country with a basic health care system on the first pandemic day. These immunomodulatory agents may represent a new approach to reduce mortality caused by seasonal and pandemic influenza [234].

In human influenza infection, the anti-viral and proinflammatory cytokine response are activated through different pathways. The induction of anti-viral response is through pre-transcriptional IFN- $\beta$ production via the activation of RIG-I/IRF-3 signaling pathway while the induction of proinflammatory cytokine response is through endosomal TLR3/HA-induced ROS-dependent NF- $\mathrm{BB}$ activation $[125,126,135,235]$. (Figure 4) NFאB activation, a prerequisite for influenza infection and influenza-induced cytokine dysregulation, is dependent on ROS. ROS also plays an important role in inflammasome activation in influenza virus infection. Hence by targeting the ROS signaling, anti-oxidant can selectively suppress the proinflammatory response without jeopardizing the anti-viral activities in influenza viral infection (Figure 4). Inhibitors of NFkB activation such as IкB kinase complex inhibitors [236], proteasome inhibitors [237,238] and anti-oxidants [239-242] reduce viral replication, attenuate cytokine dysregulation and improve survival of mice with lethal influenza infection. Among anti-oxidants with therapeutic potential to severe influenza infection [243], NAC is able to inhibit inflammasome [244,245] and NFkB [246] activation during influenza infection. NAC, at an oral dose of $1 \mathrm{~g} / \mathrm{Kg}$ daily, improved the survival of mice against lethal influenza infection [247] and was synergistic with ribavirin [248] or oseltamivir[249] in protecting mice from lethal influenza infection with an end point survival of $92 \%$ and $100 \%$ respectively (Figure 6). $\mathrm{NAC}$, at $100 \mathrm{mg} / \mathrm{Kg}$ continuous intravenous infusion daily, suppressed the fever and C-reactive protein concentration with corresponding clinical improvement in a patient with 2009 novel H1N1 influenza virus (2009PV) pneumonia [250]. NAC inhibits replication of H5N1 and reduces H5N1-induced cytopathogenic effects, apoptosis and the pro-inflammatory cytokine production [246] at a serum concentration achievable with NAC infusion for the treatment of paracetamol overdose [251]. The inhibition of replication of influenza virus is strain dependent [252]. NAC enhances the development of influenza-specific $\mathrm{CD} 8+\mathrm{T}$ cells, an important step in adaptive immunity for clearance of influenza virus $[253,254]$. Therefore, by targeting ROS-induced NF- $\kappa B$ activation, high dose NAC anti-oxidant therapy can inhibit viral replication, suppress cytokine dysregulation, and enhance the development of adaptive immunity during influenza infection. Given the poor oral availability of NAC in the range of $6 \%$ to $10 \%$ in humans, therapeutic dose of NAC for influenza infection can hardly be delivered by oral preparation [255]. NAC is a category B drug for pregnancy and is an affordable drug with a wide therapeutic window. NAC has an established safety profile even in high dose and prolonged use in humans[256-258]. With NAC's safety profile, it is ethically justifiable to validate its role in the management of cytokine dysregulation of severe influenza infection with large scale human randomized controlled trials. Selenium, a co-enzyme of glutathione peroxidase is essential in glutathione synthesis. It is able to suppress the activation of $\mathrm{NF \kappa B}$ and has been shown to reduce influenza-induced pathology. It may have a complementary role to the anti-oxidant action of N-acetylcysteine [259263]. The high selenium content of anti-influenza herbal mushrooms in traditional Chinese medicine may have contributed to their ability in protecting mice from lethal influenza infection [264].

The export of viral ribonucleoprotein (vRNP) complexes from the nucleus to the cytoplasm is a pivotal step necessary for the formation of progeny influenza virus particles [265].Caspase 3 activation is essential for nuclear vRNP export in influenza infection [115]. The influenzainduced $\mathrm{NFKB}$ activation up-regulates the pro-apoptotic factors tumor necrosis factor-related apoptosis-inducing ligand (TRAIL) and Fas/FasL pathway and induces caspase 3-dependent apoptosis to facilitate the nuclear export of vRNP complexes to enhance influenza propagation [116]. Inhibition of NFKB activation by aspirin or COX-2 inhibitor blocks caspase activation, prevents the nuclear export of vRNP complexes. and improves the survival of mice from lethal influenza infection [266,267]. Salicylate and aspirin inhibit NFKB activation by preventing the phosphorylation of IкBa and its subsequent degradation by ubiquitin-proteasome pathway $[268,269]$. Their role in the management of influenza has declined after the association with Reye's syndrome with their use in children [270]. COX-2 inhibitors are being explored recently as an alternative immunomodulating agent for the treatment of severe influenza infection [271]. COX2 inhibitors are able to suppress $\mathrm{H} 5 \mathrm{~N} 1$ virus replication in human macrophages [272]. H5N1-induced pro-inflammatory markers such as IL-6 was suppressible with celecoxib (COX-2 inhibitor), and mesalazine (5-amino salicylic acid) [273]. 5-amino salicylic acid is a

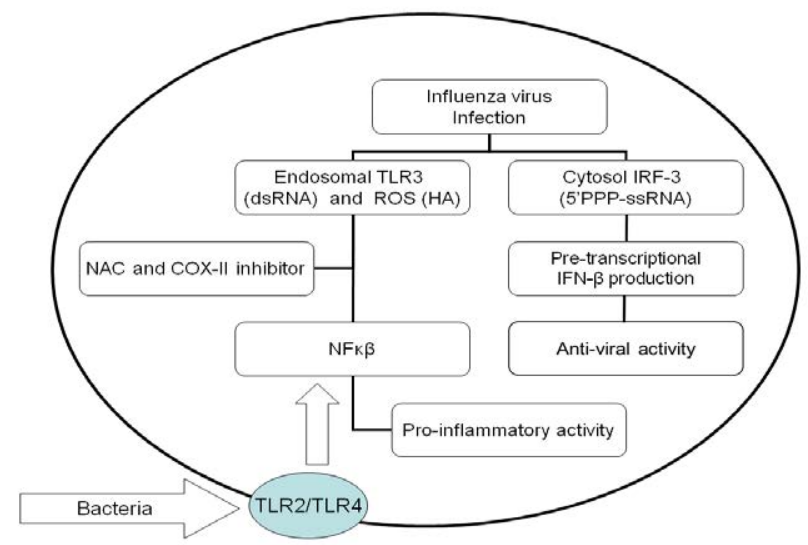

Figure 4: Schematic diagram showing the different activation pathway of pro-inflammatory and anti-viral activity in influenza infection: During the early phase of influenza infection, the induction of pro-inflammatory activity is through NFKB activation by toll-like receptor 3 (TLR3) stimulation via endosomal dsRNA and reactive oxygen species (ROS) production via haemagglutinin (HA)-induced endoplasmic reticulum overload (ER-overload) whereas the induction of early anti-viral activity is through the induction of pre-transcriptional interferon- $\beta$ (IFN- $\beta$ ) production via activation of cytosol interferon regulatory factor 3 (IRF3) by binding of retinoid-inducible gene I (RIG-I) by 5'PPP-containing single stranded RNA (5'PPP-sSRNA). Therefore, anti-oxidants COX-2 inhibitor and paracetamol by targeting the NFKB pathway can block the human pro-inflammatory activity without compromising the human antiviral response. Since gram positive and gram negative bacteria can activate NFKB through surface membrane toll like receptor 2 and 4 (TLR2/ TLR4) respectively [335-338] NAC is unable to block bacteria-induced NFKB activation. 


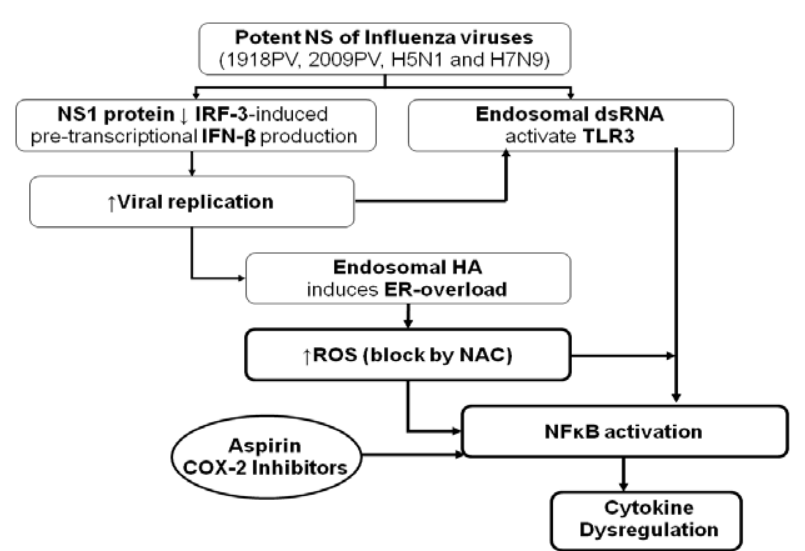

Figure 5: Schematic diagram showing the induction of cytokine dysregulation in severe influenza virus infection. Human infection with influenza viruses with a NS capable of suppressing pre-transcriptional IRF-3-induced IFN- $\beta$ production (1918PV, 2009PV, H5N1 and H7N9) allows these influenza viruses to proliferate rapidly during the stealth phase of influenza infection. This enhanced viral replication results in an accumulation of endosomal haemagglutinin (HA) and double-stranded RNA (dsRNA). The endosomal HA activates NF-KB via the production of ROS through endoplasmic reticulum overload (ER-overload). ROS enhances TLR3 induced NFKB activation in reaction to an accumulated endosomal viral dsRNA. Profound activation of NFKB by accumulated endosomal $\mathrm{HA}$ and dsRNA results in cytokine dysregulation. Since NFKB activation is a prerequisite for influenza-induced cytokine dysregulation, blockade of NF-KB activation by NAC, paracetamol and COX-2 inhibitors leads to suppression of cytokine dysregulation in influenza infection.

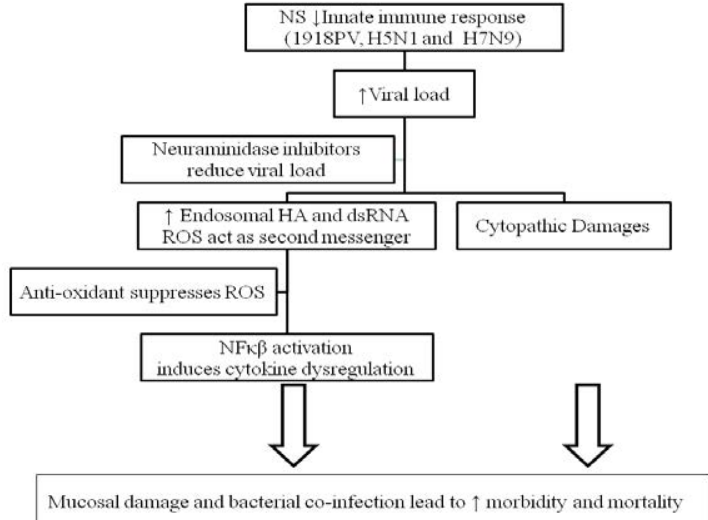

Figure 6: Influenza viruses (1918PV, H5N1 and H7N9) with potent innate immune response suppressing NS induce a heavy viral load which in turn leads to direct cytopathic damage and an accumulation of endosomal haemagglutinin (HA) and double-stranded RNA (dsRNA). ROS then acts as the second messenger for both dsRNA and HA induced NFKB activation to induce cytokine dysregulation. The cytopathic damage and cytokine dysregulation result in an enhanced morbidity and mortality. Either mechanism of tissue damage may predominate in an individual patient. Neuraminidase inhibitors reduce viral load. Anti-oxidant at a dose that can suppress endosomal ROS reduces influenza-induced cytokine dysregulation. This may explain the synergistic action of neuraminidase inhibitor and high-dose NAC in reducing mortality in mice with lethal influenza infection.

derivative of salicylic acid with anti-oxidant property for the treatment of inflammatory bowel disease [274]. Paracetamol has been shown to significantly decrease the infiltration of inflammatory cells into the airway spaces, reduced pulmonary immunopathology associated with acute infection and improved the overall lung function of mice, without adversely affecting the induction of virus-specific adaptive responses [275]. The role of paracetamol and COX-2 inhibitors in the management of influenza virus induced cytokine dysregulation should be confirmed by prospective randomized studies in humans (Figure 5).

Apart from control of cytokine dysregulation, reduction in viral load is pivotal to survival in influenza virus infection. Although blockage of NF-kB activation can abolish cytokine dysregulation, it is unable to prevent apoptosis of the host cells because influenza virus also induce extracellular $\mathrm{Ca} 2+$ influx, leading to mitochondrial dysfunction to induce host cell apoptosis [276,277]. Influenza virusinduced accelerated extracellular $\mathrm{Ca} 2+$ influx are critical for influenza replication [278]. Early neuraminidase inhibitor therapy reduces viral load and improves survival in 2009PV and H5N1 infection in humans $[279,280]$. Patients receiving treatment within 48 hours after symptom onset of $\mathrm{H} 5 \mathrm{~N} 1$ infection have the best survival benefit with a mortality of $20 \%$. The mortality of $\mathrm{H} 5 \mathrm{~N} 1$ was $76 \%$ in the absence of anti-viral therapy [281]. Neuraminidase inhibitors are complementary to NAC and COX-2 inhibitors in improving the survival of mice in lethal influenza infection probably by controlling the viral load and influenzainduced apoptosis. A triple therapy with a combination of zanamivir, celecoxib (COX-2 inhibitor), and mesalazine reduce viral load and inflammatory marker and improve survival of mice with lethal $\mathrm{H} 5 \mathrm{~N} 1$ avian influenza infection. Zanamivir alone reduced viral load but not inflammation and mortality. The survival benefits of adding celecoxib and mesalazine to zanamivir could be caused by their synergistic effects in reducing cytokine dysregulation [282].

\section{Future Perspectives}

Although no significant antigenic changes in circulating 2009PV strains compared with vaccine strains have been detected since 2009, seasonal novel H1N1 influenza in 2013-14 influenza seasons produced an enhance mortality and $\mathrm{W}$-shaped mortality age distribution $[10,11,283,284]$. Besides monitoring the antigenic drift in hemagglutinin and neuraminidase gene segment, the surveillance of NS mutation is also necessary to determine whether the NS1 protein adapatation of novel H1N1 influenza A virus to human CPSF30 may have contributed to the adverse clinical outcome of 2009PV infection in 2014. The virulence of $\mathrm{H} 3 \mathrm{~N} 2$ may increase if this potent innate immune suppressing NS of 2009PV is reassorted to seasonal H3N2 during transmission in humans.

A potent innate suppressing NS capable of inhibiting human pretranscriptional IFN- $\beta$ production has emerged in highly pathogenic H5N1 and low pathogenic H7N9 avian influenza viruses [26,285]. This had resulted in cytokine dysregulation [225,286-288] and an enhanced mortality $[289,290]$ in human infections by these viruses. The H5N1 responsible for the human outbreak in 1997 (A/HK/97/ $\mathrm{H} 5 \mathrm{~N} 1$ ) produced a mortality of $33 \%$ [291]. A/HK/97/H5N1 contained an NS capable of suppressing constitutive IFN- $\beta$ release [292] and inducible IFN- $\beta$ production at the pre-transcriptional level [26]. The NS1 protein of A/HK/97/H5N1, which contains an L103 and I106 structure, binds human CPSF30 to a significant, though not optimum extent [293]. Over $98 \%$ of the NS1 proteins of H5N1 isolated from humans after 2003 contain the F103 and M106 amino acid structures that bind optimally to human CPSF30 [294]. The mutation results in a 20-fold enhancement in virus replication in tissue culture and 250fold enhancement of virulence in mice [295,296]. Human infection with H5N1 after 2003 has a mortality of 55\% [297]. This unique potent innate immune suppressing NS of influenza A/HK/97/H5N1 is also present in H9N2 $[298,299]$ and H6N1 $[300,301]$ avian influenza viruses endemic in China. Constitutive interferon-beta (IFN- $\beta$ ) and inducible type I interferon (IFN- $\alpha / \beta)$ are complementary in protection against 
influenza infection. Low level of constitutively produced IFN- $\beta$ is important to maintain immune cells in an activated state ready for a timely response for the production of inducible interferon to influenza infection [302-304].The suppression of both constitutive and inducible interferon at multiple levels may account for the enhanced mortality in human H5N1 infection $[26,292,294]$ (Figure 7). The intense innate immune suppression conferred by this NS enhances tropism of $\mathrm{H} 5 \mathrm{~N} 1$ for human tissues and allows H5N1 to invade and replicate in human tissues without the need for the avian sialic acid alpha-2,6-galactose receptor [305-308]. Introduction of the NS of H5N1 into the highly pathogenic $\mathrm{H} 7 \mathrm{~N} 1$ avian influenza virus enabled $\mathrm{H} 7 \mathrm{~N} 1$ to replicate efficiently in different human cell lines without prior adaptation. The enhanced viral replication and tissue tropism were attributed to a stronger suppression of IFN- $\beta$ production and better binding efficiency of the NS1 protein to human CPSF30. This observation shows that the NS of $\mathrm{H} 5 \mathrm{~N} 1$ is able to increase the virulence and enhance the adaptation of avian influenza viruses to human hosts [309,310].This potent NS of H5N1 that had resided in H9N2 influenza viruses had reassorted into low pathogenic H7N9 avian influenza virus [311314 ], leading to a mortality of $33 \%$ during the first human outbreak of H7N9 in China in 2013 [315]. The NS1 protein of H7N9 exert potent inhibition of RIG-I-dependent upregulation of the IFN- $\beta$ promotor in human cells and allow H7N9 to replicate efficiently in human alveolar tissue. Although NS1 protein of H7N9 can inhibit IFN- $\beta$ at the pretranscriptional level, it has suboptimal binding to CPSF30 to allow it to block interferon production at the post-transcriptional level, a situation similar to A/HK/97/H5N1 in 1997 [316]. The presence of this human adapted potent innate immune suppressing NS in low pathogenic avian influenza viruses endemic in China may give rise to the emergence of highly lethal reassortant avian influenza viruses with pandemic potential through the poultry market in China [317]. Outbreak of human avian influenza virus infection in China and South East Asia usually occurs during the months around the Chinese New Year when poultry movement and sales grow exponentially [318-321].

There is an evidence for a protective effect of influenza immunization against bacterial infections, and vice versa of pneumococcal vaccination against influenza-associated pneumonia and lethality [322]. While antibiotics and vaccines will certainly reduce the rate of individual mortality, the factor contributing most to the relatively lower anticipated lethality of a pandemic with a 1918-like influenza virus in contemporary population is to reduce bacterial coinfection, in particular Streptococcus pneumonia [323]. This can be achieved through vaccination policy and smoking cessation campaign. Pandemic preparedness plans against novel influenza viruses such as $\mathrm{H} 5 \mathrm{~N} 1 / \mathrm{H} 7 \mathrm{~N} 9$ avian influenza viruses should consolidate existing pneumococcal vaccination program, in particular among persons aged 18-64 years who are at risk of pneumococcal disease [324]. Pneumococcal vaccination program should expand to include healthy young adults in between 20 to 40 years of age in anticipation of an W-shaped mortality distribution of 2009PV and H5N1 avian influenza viruses infection $[54,188,325]$. Smoking cessation campaign should be incorporated into national pandemic preparedness plans in countries where tobacco smoking is highly prevalent. The world should be working towards a tobacco free initiative on both national and global levels as promoted by the World Health Organization [326].

Cytokine dysregulation is a common feature in 1918PV, 2009PV, H5N1, and H7N9 infection and contributes to influenza-related mortality. In the event of a human $\mathrm{H} 7 \mathrm{~N} 9 / \mathrm{H} 5 \mathrm{~N} 1$ avian influenza pandemic that carries a mortality of over $30 \%$, more than $85 \%$ of the world's population will not have meaningful access to pandemic vaccines or antiviral agents [327]. From the experience of the novel H1N1 pandemic, pandemic vaccines are unlikely to be available for effective prevention during the first wave of a pandemic [328,329], and non-pharmaceutical interventions such as quarantine and containment failed to contain the pandemic in the initial mitigation phase even in developed countries [330]. In combating such unprecedented global public-health crisis, additional rapidly activated intervention measures that may control influenza-induced cytokine dysregulation will be required if high mortality rate are to be avoided [331]. Research is urgently needed to determine whether alternative treatments that are inexpensive, can be stockpiled and would be available on the first pandemic day might be useful in managing the cytokine dysregulation of human H7N9/H5N1 avian influenza infection [332]. Since interferoninduced transmembrane protein-3 dysfunction that predisposed an individual to cytokine dysregulation and an enhanced mortality in severe influenza infection such as H7N9/H5N1 avian influenza virus is more common in Han Chinese [226,333,334], medications that can effectively suppress cytokine dysregulation without impairing the human anti-viral response is urgently needed for strategic preparation of a $\mathrm{H} 7 \mathrm{~N} 9 / \mathrm{H} 5 \mathrm{~N} 1$ pandemic in China. By targeting the NFkB and inflammasome activation pathway, high dose NAC anti-oxidant therapy, paracetamol and COX2 inhibitors may have a complementary role to anti-viral agents in the management of influenza-induced cytokine dysregulation. If the efficacy of these agents against human $\mathrm{H} 7 \mathrm{~N} 9 / \mathrm{H} 5 \mathrm{~N} 1$ avian influenza virus infection is confirmatory, the availability and affordability of these agents make them ideal medications in pandemic situation and for use in countries with limited resources. It may also signify a major breakthrough in the future management of all human influenza A induced cytokine dysregulation as these medications are directed against non-mutable determinants of the host common to the pathogenesis of all influenza A viruses.

\section{Authors' contributions}

KY Lai and GWY NG contributed to the conception and drafting of the manuscript. KY Lai, GWY Ng contributed to the conception

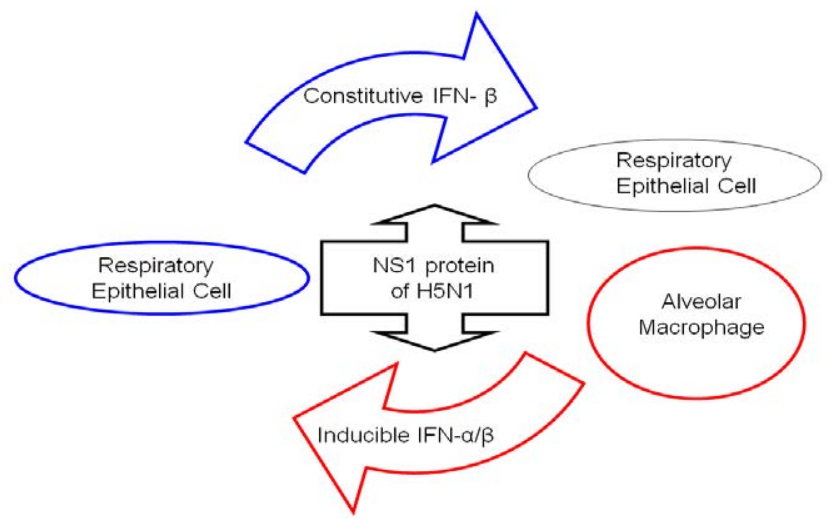

Figure 7: Schematic diagram showing the important complementary role of constitutive IFN- $\beta$ and inducible type I interferon (IFN- $\alpha / \beta)$ during influenza infection: The respiratory epithelial cell has a basal secretion of constitutive IFN- $\beta$ to maintain the alveolar macrophage in a primed state for timely production of IFN- $\alpha / \beta$ in response to influenza infection. The release of constitutive IFN- $\beta$ by influenza infected respiratory epithelial cell allows the activation of interferon-related genes in the respiratory epithelial cell during the early phase of influenza infection. The inducible IFN- $\alpha / \beta$ released from infected alveolar macrophages initiates antiviral signaling, triggers apoptosis and limits influenza replication in the respiratory epithelial cells in the early phase of influenza infection. The NS1 protein of H5N1 isolated in humans after 2003 can inhibit release of constitutive IFN- $\beta$ and production of inducible IFN- $\beta$ at the pre-transcriptional level and IFN- $\alpha / \beta$ at the post-transcriptional level. 
Citation: Lai KY, Wing Yiu George NG, Cheng FF (2015)The W-Shaped Mortality-Age Distribution of Novel H1N1 Influenza Virus Helps Reconstruct the Second Wave of Pandemic 1918 Spanish Flu. J Pulm Respir Med 5: 245. doi:10.4172/2161-105X.1000245

and writing of the manuscript. All authors have read and approved the manuscript. This paper is dedicated to Johnny Sze Wah LAU, Mei Yin HO and Fuk Hong LAI.

\section{References}

1. Westall GP, Paraskeva M (2011) H1N1 influenza: critical care aspects. Semin Respir Crit Care Med 32: 400-408.

2. Ison MG, Lee N (2010) Influenza 2010-2011: lessons from the 2009 pandemic. Cleve Clin J Med 77: 812-820.

3. Zangrillo A, Biondi-Zoccai G, Landoni G, Frati G, Patroniti N, et al. (2013) Extracorporeal membrane oxygenation (ECMO) in patients with $\mathrm{H} 1 \mathrm{~N} 1$ influenza infection: a systematic review and meta-analysis including 8 studies and 266 patients receiving ECMO. Crit Care 17: R30.

4. Faruqui F, Mukundan D (2010) 2009 pandemic influenza: a review. Curr Opin Pediatr 22: 530-535.

5. Chowell G, Bertozzi SM, Colchero MA, Lopez-Gatell H, Alpuche-Aranda C, et al. (2009) Severe respiratory disease concurrent with the circulation of H1N1 influenza. N Engl J Med 361: 674-679.

6. Kumar A, Zarychanski R, Pinto R, Cook DJ, Marshall J, et al. (2009) Critically ill patients with 2009 influenza A(H1N1) infection in Canada. JAMA 302: 18721879.

7. Shrestha SS, Swerdlow DL, Borse RH, Prabhu VS, Finelli L, et al. (2011) Estimating the burden of 2009 pandemic influenza A (H1N1) in the United States (April 2009-April 2010). Clin Infect Dis 52 Suppl 1: S75-82.

8. CDC (2010) Prevention and control of influenza with vaccines: recommendations of the Advisory Committee on Immunization Practices (ACIP) 2010. MMWR 59.

9. CDC: Influenza Vaccination: A Summary for Clinicians.

10. Arriola CS, Brammer L, Epperson S, Blanton L, Kniss K, et al. (2014) Update: influenza activity - United States, September 29, 2013-February 8, 2014. MMWR Morb Mortal Wkly Rep 63: 148-154.

11. Napolitano LM, Angus DC, Uyeki TM (2014) Critically ill patients with influenza $\mathrm{A}(\mathrm{H} 1 \mathrm{~N} 1)$ pdm09 virus infection in 2014. JAMA 311: 1289-1290.

12. Morens DM, Taubenberger JK (2010) Historical thoughts on influenza viral ecosystems, or behold a pale horse, dead dogs, failing fowl, and sick swine. Influenza Other Respir Viruses 4: 327-337.

13. World Health Organization (2005) Ten things you need to know about pandemic influenza (update of 14 October 2005). Wkly Epidemiol Rec 80: 428-431.

14. Miller MA, Viboud C, Balinska M, Simonsen L (2009) The signature features of influenza pandemics--implications for policy. N Engl J Med 360: 2595-2598.

15. Taubenberger JK, Morens DM (2006) 1918 Influenza: the mother of all pandemics. Emerg Infect Dis 12: 15-22.

16. Conzelmann KK (2005) Transcriptional activation of alpha/beta interferon genes: interference by nonsegmented negative-strand RNA viruses. J Virol 79: 5241-5248.

17. Koerner I, Kochs G, Kalinke U, Weiss S, Staeheli P (2007) Protective role of beta interferon in host defense against influenza A virus. J Virol 81: 2025-2030.

18. Kochs G, García-Sastre A, Martínez-Sobrido L (2007) Multiple anti-interferon actions of the influenza A virus NS1 protein. J Virol 81: 7011-7021.

19. Smith W, Andrewes CH, Laidlaw PP (1933) Virus obtained from influenza patients. Lancet 2: 66-68.

20. Taubenberger JK, Reid AH, Krafft AE, Bijwaard KE, Fanning TG (1997) Initial genetic characterization of the 1918 "Spanish" influenza virus. Science 275: 1793-1796.

21. Geiss GK, Salvatore M, Tumpey TM, Carter VS, Wang X, et al. (2002) Cellular transcriptional profiling in influenza $A$ virus-infected lung epithelial cells: the role of the nonstructural NS1 protein in the evasion of the host innate defense and its potential contribution to pandemic influenza. Proc Natl Acad Sci U S A 99: 10736-10741.

22. Palese P, Basler CF, García-Sastre A (2002) The makings of a killer. Nat Med 8: 927-928.

23. Taubenberger JK (2005) The virulence of the 1918 pandemic influenza virus: unraveling the enigma. Arch Virol Suppl : 101-115.
24. Meunier I, von Messling V (2011) NS1-mediated delay of type I interferon induction contributes to influenza A virulence in ferrets. J Gen Virol 92: 16351644.

25. Billharz R, Zeng H, Proll SC, Korth MJ, Lederer S, et al. (2009) The NS1 protein of the 1918 pandemic influenza virus blocks host interferon and lipid metabolism pathways. J Virol 83: 10557-10570.

26. Kuo RL, Zhao C, Malur M, Krug RM (2010) Influenza A virus strains that circulate in humans differ in the ability of their NS1 proteins to block the activation of IRF3 and interferon-Î² transcription. Virology 408: 146-158.

27. Hale BG, Steel J, Medina RA, Manicassamy B, Ye J, et al. (2010) Inefficient control of host gene expression by the 2009 pandemic H1N1 influenza A virus NS1 protein. J Virol 84: 6909-6922.

28. Yu WC, Chan RW, Wang J, Travanty EA, Nicholls JM, et al. (2011) Vira replication and innate host responses in primary human alveolar epithelial cells and alveolar macrophages infected with influenza H5N1 and H1N1 viruses. J Virol 85: 6844-6855.

29. Perrone LA, Plowden JK, García-Sastre A, Katz JM, Tumpey TM (2008) H5N1 and 1918 pandemic influenza virus infection results in early and excessive infiltration of macrophages and neutrophils in the lungs of mice. PLoS Pathog 4: e1000115.

30. Kobasa D, Jones SM, Shinya K, Kash JC, Copps J, et al. (2007) Aberrant innate immune response in lethal infection of macaques with the 1918 influenza virus. Nature 445: $319-323$

31. Tumpey TM, García-Sastre A, Taubenberger JK, Palese P, Swayne DE, et al. (2005) Pathogenicity of influenza viruses with genes from the 1918 pandemic virus: functional roles of alveolar macrophages and neutrophils in limiting virus replication and mortality in mice. J Virol 79: 14933-14944.

32. Memoli MJ, Tumpey TM, Jagger BW, Dugan VG, Sheng ZM, et al. (2009) An early 'classical' swine H1N1 influenza virus shows similar pathogenicity to the 1918 pandemic virus in ferrets and mice. Virology 393: 338-345.

33. Garten RJ, Davis CT, Russell CA, Shu B, Lindstrom S, et al. (2009) Antigenic and genetic characteristics of swine-origin $2009 \mathrm{~A}(\mathrm{H} 1 \mathrm{~N} 1)$ influenza viruses circulating in humans. Science 325: 197-201.

34. Itoh Y, Shinya K, Kiso M, Watanabe T, Sakoda Y, et al. (2009) In vitro and in vivo characterization of new swine-origin H1N1 influenza viruses. Nature 460: 1021-1025.

35. Simonsen L, Spreeuwenberg P, Lustig R, Taylor RJ, Fleming DM, et al. (2013) Global mortality estimates for the 2009 Influenza Pandemic from the GLaMOR project: a modeling study. PLoS Med 10: e1001558.

36. Hale BG, Steel J, Manicassamy B, Medina RA, Ye J, et al. (2010) Mutations in the NS1 C-terminal tail do not enhance replication or virulence of the 2009 pandemic H1N1 influenza A virus. J Gen Virol 91: 1737-1742.

37. Ozawa M, Basnet S, Burley LM, Neumann G, Hatta M, et al. (2011) Impact of amino acid mutations in PB2, PB1-F2, and NS1 on the replication and pathogenicity of pandemic (H1N1) 2009 influenza viruses. J Virol 85: 45964601.

38. Fernandez-Sesma A (2007) The influenza virus NS1 protein: inhibitor of innate and adaptive immunity. Infect Disord Drug Targets 7: 336-343.

39. Fernandez-Sesma A, Marukian S, Ebersole BJ, Kaminski D, Park MS, et al. (2006) Influenza virus evades innate and adaptive immunity via the NS1 protein. J Virol 80: 6295-6304.

40. Tisoncik JR, Billharz R, Burmakina S, Belisle SE, Proll SC, et al. (2011) The NS1 protein of influenza A virus suppresses interferon-regulated activation of antigen-presentation and immune-proteasome pathways. J Gen Virol 92: 20932104.

41. Goodman AG, Zeng H, Proll SC, Peng X, Cillóniz C, et al. (2010) The alpha/ beta interferon receptor provides protection against influenza virus replication but is dispensable for inflammatory response signaling. J Virol 84: 2027-2037.

42. Julkunen I, Sareneva T, Pirhonen J, Ronni T, Melén K, et al. (2001) Molecular pathogenesis of influenza $A$ virus infection and virus-induced regulation of cytokine gene expression. Cytokine Growth Factor Rev 12: 171-180.

43. To KK, Hung IF, Li IW, Lee KL, Koo CK, et al. (2010) Delayed clearance of vira load and marked cytokine activation in severe cases of pandemic H1N1 2009 influenza virus infection. Clin Infect Dis 50: 850-859.

44. Lee N, Chan PK, Hui DS, Rainer TH, Wong E, et al. (2009) Viral loads and duration of viral shedding in adult patients hospitalized with influenza. J Infect 
Citation: Lai KY, Wing Yiu George NG, Cheng FF (2015)The W-Shaped Mortality-Age Distribution of Novel H1N1 Influenza Virus Helps Reconstruct the Second Wave of Pandemic 1918 Spanish Flu. J Pulm Respir Med 5: 245. doi:10.4172/2161-105X.1000245

Page 11 of 17

Dis 200: 492-500.

45. Gorini da Veiga AB, Kretzmann NA, Corrêa LT, Goshiyama AM, Baccin T, et al. (2012) Viral load and epidemiological profile of patients infected by pandemic influenza a (H1N1) 2009 and seasonal influenza a virus in Southern Brazil. J Med Virol 84: 371-379.

46. Li CC, Wang L, Eng HL, You HL, Chang LS, et al. (2010) Correlation of pandemic (H1N1) 2009 viral load with disease severity and prolonged viral shedding in children. Emerg Infect Dis 16: 1265-1272.

47. Josset L, Belser JA, Pantin-Jackwood MJ, Chang JH, Chang ST, et al. (2012) Implication of inflammatory macrophages, nuclear receptors, and interferon regulatory factors in increased virulence of pandemic 2009 H1N1 influenza A virus after host adaptation. J Virol 86: 7192-7206.

48. Lee N, Wong CK, Chan PK, Chan MC, Wong RY, et al. (2011) Cytokine response patterns in severe pandemic $2009 \mathrm{H} 1 \mathrm{~N} 1$ and seasonal influenza among hospitalized adults. PLoS One 6: e26050.

49. Bermejo-Martin JF, Ortiz de Lejarazu R, Pumarola T, Rello J, Almansa R, et al. (2009) Th1 and Th17 hypercytokinemia as early host response signature in severe pandemic influenza. Crit Care 13: R201.

50. Yu X, Zhang X, Zhao B, Wang J, Zhu Z, et al. (2011) Intensive cytokine induction in pandemic $\mathrm{H} 1 \mathrm{~N} 1$ influenza virus infection accompanied by robust production of IL-10 and IL-6. PLoS One 6: e28680.

51. Hall MW, Geyer SM, Guo CY, Panoskaltsis-Mortari A, Jouvet P, et al. (2013) Innate immune function and mortality in critically ill children with influenza: a multicenter study. Crit Care Med 41: 224-236.

52. Lee N, Chan PK, Lui GC, Wong BC, Sin WW, et al. (2011) Complications and outcomes of pandemic 2009 Influenza A (H1N1) virus infection in hospitalized adults: how do they differ from those in seasonal influenza? J Infect Dis 203 $1739-1747$.

53. Lucas S (2010) Predictive clinicopathological features derived from systematic autopsy examination of patients who died with $\mathrm{A} / \mathrm{H} 1 \mathrm{~N} 1$ influenza infection in the UK 2009-10 pandemic. Health Technol Assess 14: 83-114.

54. Perez-Padilla R, de la Rosa-Zamboni D, Ponce de Leon S, Hernandez M, Quiñones-Falconi F, et al. (2009) Pneumonia and respiratory failure from swine-origin influenza A (H1N1) in Mexico. N Engl J Med 361: 680-689.

55. Giamarellos-Bourboulis EJ, Raftogiannis M, Antonopoulou A, Baziaka F, Koutoukas P, et al. (2009) Effect of the novel influenza A (H1N1) virus in the human immune system. PLoS One 4: e8393.

56. Cox CM, Blanton L, Dhara R, Brammer L, Finelli L (2011) 2009 Pandemic influenza A (H1N1) deaths among children--United States, 2009-2010. Clin Infect Dis 52 Suppl 1: S69-74.

57. Dawood FS, luliano AD, Reed C, Meltzer MI, Shay DK, et al. (2012) Estimated global mortality associated with the first 12 months of 2009 pandemic influenza A H1N1 virus circulation: a modelling study. Lancet Infect Dis 12: 687-695.

58. Rothberg MB, Haessler SD, Brown RB (2008) Complications of viral influenza. Am J Med 121: 258-264.

59. Florescu DF, Kalil AC (2014) The complex link between influenza and severe sepsis. Virulence 5: 137-142.

60. Mina MJ, Klugman KP (2013) Pathogen replication, host inflammation, and disease in the upper respiratory tract. Infect Immun 81: 625-628.

61. Joseph C, Togawa Y, Shindo N (2013) Bacterial and viral infections associated with influenza. Influenza Other Respir Viruses 7 Suppl 2: 105-113.

62. Terpenning M, Bretz W, Lopatin D, Langmore S, Dominguez B, et al. (1993) Bacterial colonization of saliva and plaque in the elderly. Clin Infect Dis 16 Suppl 4: S314-316

63. Principi N, Marchisio P, Schito GC, Mannelli S (1999) Risk factors for carriage of respiratory pathogens in the nasopharynx of healthy children. Ascanius Project Collaborative Group. Pediatr Infect Dis J 18: 517-523.

64. Kwambana BA, Barer MR, Bottomley C, Adegbola RA, Antonio M (2011) Early acquisition and high nasopharyngeal co-colonisation by Streptococcus pneumoniae and three respiratory pathogens amongst Gambian new-borns and infants. BMC Infect Dis 11: 175.

65. García-Rodríguez JA, Fresnadillo Martínez MJ (2002) Dynamics of nasopharyngeal colonization by potential respiratory pathogens. J Antimicrob Chemother 50 Suppl S2: 59-73.

66. Bosch AA, Biesbroek G, Trzcinski K, Sanders EA, Bogaert D (2013) Viral and bacterial interactions in the upper respiratory tract. PLoS Pathog 9: e1003057.

67. Bogaert D, De Groot R, Hermans PW (2004) Streptococcus pneumoniae colonisation: the key to pneumococcal disease. Lancet Infect Dis 4: 144-154.

68. Tenenbaum T, Franz A, Neuhausen N, Willems R, Brade J, et al. (2012) Clinica characteristics of children with lower respiratory tract infections are dependent on the carriage of specific pathogens in the nasopharynx. Eur J Clin Microbiol Infect Dis 31: $3173-3182$

69. Wang XY, Kilgore PE, Lim KA, Wang SM, Lee J, et al. (2011) Influenza and bacterial pathogen coinfections in the 20th century. Interdiscip Perspect Infect Dis 2011: 146376 .

70. Mojon P (2002) Oral health and respiratory infection. J Can Dent Assoc 68 : 340-345.

71. Sumi Y, Kagami H, Ohtsuka Y, Kakinoki Y, Haruguchi Y, et al. (2003) High correlation between the bacterial species in denture plaque and pharyngeal microflora. Gerodontology 20: 84-87.

72. El-Solh AA, Pietrantoni C, Bhat A, Okada M, Zambon J, et al. (2004) Colonization of dental plaques: a reservoir of respiratory pathogens for hospital-acquired pneumonia in institutionalized elders. Chest 126: 1575-1582.

73. Paju S, Scannapieco FA (2007) Oral biofilms, periodontitis, and pulmonary infections. Oral Dis 13: 508-512.

74. Mouton CP, Bazaldua OV, Pierce B, Espino DV (2001) Common infections in older adults. Am Fam Physician 63: 257-268.

75. Voordouw BC, van der Linden PD, Simonian S, van der Lei J, Sturkenboom MC, et al. (2003) Influenza vaccination in community-dwelling elderly: impact on mortality and influenza-associated morbidity. Arch Intern Med 163: 10891094.

76. Christenson B, Hedlund J, Lundbergh P, Ortqvist A (2004) Additive preventive effect of influenza and pneumococcal vaccines in elderly persons. Eur Respir J 23: 363-368.

77. Mahamat A, Daurès JP, de Wzieres B (2013) Additive preventive effect of influenza and pneumococcal vaccines in the elderly: results of a large cohort study. Hum Vaccin Immunother 9: 128-135.

78. Florescu DF, Kalil AC (2014) The complex link between influenza and severe sepsis. Virulence 5: 137-142.

79. Morens DM, Taubenberger JK, Harvey HA, Memoli MJ (2010) The 1918 influenza pandemic: lessons for 2009 and the future. Crit Care Med 38: e10-20.

80. Morens DM, Taubenberger JK, Fauci AS (2008) Predominant role of bacteria pneumonia as a cause of death in pandemic influenza: implications for pandemic influenza preparedness. J Infect Dis 198: 962-970.

81. García-Sastre A, Durbin RK, Zheng H, Palese P, Gertner R, et al. (1998) The role of interferon in influenza virus tissue tropism. J Virol 72: 8550-8558.

82. Haller O, Arnheiter H, Gresser I, Lindenmann J (1979) Genetically determined interferon-dependent resistance to influenza virus in mice. J Exp Med 149: 601 612

83. García-Sastre A, Egorov A, Matassov D, Brandt S, Levy DE, et al. (1998) Influenza A virus lacking the NS1 gene replicates in interferon-deficient systems. Virology 252: 324-330.

84. Wang $X$, Li M, Zheng H, Muster T, Palese $P$, et al. (2000) Influenza A virus NS1 protein prevents activation of NF-kappaB and induction of alpha/beta interferon. J Virol 74: 11566-11573.

85. Palese P, Muster T, Zheng H, O’Neill R, Garcia-Sastre A (1999) Learning from ou foes: a novel vaccine concept for influenza virus. Arch Virol Suppl 15: 131-138.

86. Cauthen AN, Swayne DE, Sekellick MJ, Marcus PI, Suarez DL (2007) Amelioration of influenza virus pathogenesis in chickens attributed to the enhanced interferon-inducing capacity of a virus with a truncated NS1 gene. J Virol 81: 1838-1847.

87. Steel J, Lowen AC, Pena L, Angel M, Solórzano A, et al. (2009) Live attenuated influenza viruses containing NS1 truncations as vaccine candidates agains H5N1 highly pathogenic avian influenza. J Virol 83: 1742-1753.

88. Mueller SN, Langley WA, Carnero E, García-Sastre A, Ahmed R (2010) Immunization with live attenuated influenza viruses that express altered NS1 proteins results in potent and protective memory CD8+ T-cell responses. J Virol 84: 1847-1855. 
Citation: Lai KY, Wing Yiu George NG, Cheng FF (2015)The W-Shaped Mortality-Age Distribution of Novel H1N1 Influenza Virus Helps Reconstruct the Second Wave of Pandemic 1918 Spanish Flu. J Pulm Respir Med 5: 245. doi:10.4172/2161-105X.1000245

Page 12 of 17

89. Mibayashi M, Martínez-Sobrido L, Loo YM, Cárdenas WB, Gale M Jr, et al. (2007) Inhibition of retinoic acid-inducible gene I-mediated induction of beta interferon by the NS1 protein of influenza A virus. J Virol 81: 514-524.

90. Guo Z, Chen LM, Zeng H, Gomez JA, Plowden J, et al. (2007) NS1 protein of influenza A virus inhibits the function of intracytoplasmic pathogen sensor, RIG-I. Am J Respir Cell Mol Biol 36: 263-269.

91. Talon J, Horvath CM, Polley R, Basler CF, Muster T, et al. (2000) Activation of interferon regulatory factor 3 is inhibited by the influenza A virus NS1 protein. J Virol 74: 7989-7996.

92. Opitz B, Rejaibi A, Dauber B, Eckhard J, Vinzing M, et al. (2007) IFNbeta induction by influenza A virus is mediated by RIG-I which is regulated by the viral NS1 protein. Cell Microbiol 9: 930-938.

93. Qiu Y, Krug RM (1994) The influenza virus NS1 protein is a poly(A)-binding protein that inhibits nuclear export of mRNAs containing poly(A). J Virol 68: $2425-2432$.

94. Chen Z, Krug RM (2000) Selective nuclear export of viral mRNAs in influenzavirus-infected cells. Trends Microbiol 8: 376-383.

95. Nemeroff ME, Barabino SM, Li Y, Keller W, Krug RM (1998) Influenza virus NS1 protein interacts with the cellular $30 \mathrm{kDa}$ subunit of CPSF and inhibits 3'end formation of cellular pre-mRNAs. Mol Cell 1: 991-1000.

96. Schneider J, Wolff T (2009) Nuclear functions of the influenza A and B viruses NS1 proteins: do they play a role in viral mRNA export? Vaccine 27: 6312-6316.

97. Moltedo B, López CB, Pazos M, Becker MI, Hermesh T, et al. (2009) Cutting edge: stealth influenza virus replication precedes the initiation of adaptive immunity. J Immunol 183: 3569-3573.

98. Herfst S, van den Brand JM, Schrauwen EJ, de Wit E, Munster VJ, et al (2010) Pandemic 2009 H1N1 influenza virus causes diffuse alveolar damage in cynomolgus macaques. Vet Pathol 47: 1040-1047.

99. Guarner J, Falcón-Escobedo R (2009) Comparison of the pathology caused by H1N1, H5N1, and H3N2 influenza viruses. Arch Med Res 40: 655-661.

100. Vogel AJ, Harris S, Marsteller N, Condon SA, Brown DM (2014) Early cytokine dysregulation and viral replication are associated with mortality during lethal influenza infection. Viral Immunol 27: 214-224.

101.Boon AC, Finkelstein D, Zheng M, Liao G, Allard J, et al. (2011) H5N1 influenza virus pathogenesis in genetically diverse mice is mediated at the level of viral load. MBio 2.

102. Yasuko Hatta, Karen Hershberger, Kyoko Shinya, Sean C. Proll, Richard R, et al. (2010) Viral Replication Rate Regulates Clinical Outcome and CD8 T Cel Responses during Highly Pathogenic H5N1 Influenza Virus Infection in Mice PLoS Pathog 6: e1001139.

103. Cilloniz C, Pantin-Jackwood MJ, Ni C, Goodman AG, Peng X, et al. (2010) Lethal dissemination of H5N1 influenza virus is associated with dysregulation of inflammation and lipoxin signaling in a mouse model of infection. J Virol 84 : 7613-7624.

104. Cillóniz C, Shinya K, Peng X, Korth MJ, Proll SC, et al. (2009) Lethal influenza virus infection in macaques is associated with early dysregulation of inflammatory related genes. PLoS Pathog 5: e1000604.

105. Basler CF, Reid AH, Dybing JK, Janczewski TA, Fanning TG, et al. (2001) Sequence of the 1918 pandemic influenza virus nonstructural gene (NS) segment and characterization of recombinant viruses bearing the 1918 NS genes. Proc Natl Acad Sci U S A 98: 2746-2751.

106. Smith JH, Nagy T, Driskell E, Brooks P, Tompkins SM, et al. (2011) Comparative pathology in ferrets infected with $\mathrm{H} 1 \mathrm{~N} 1$ influenza $\mathrm{A}$ viruses isolated from different hosts. J Virol 85: 7572-7581.

107. Kash JC, Tumpey TM, Proll SC, Carter V, Perwitasari O, et al. (2006) Genomic analysis of increased host immune and cell death responses induced by 1918 influenza virus. Nature 443: 578-581.

108. van den Brand JM, Stittelaar KJ, van Amerongen G, Rimmelzwaan GF, Simon $J$, et al. (2010) Severity of pneumonia due to new H1N1 influenza virus in ferrets is intermediate between that due to seasonal $\mathrm{H} 1 \mathrm{~N} 1$ virus and highly pathogenic avian influenza H5N1 virus. J Infect Dis 201: 993-999.

109. Kang YM, Song BM, Lee JS, Kim HS, Seo SH (2011) Pandemic H1N1 influenza virus causes a stronger inflammatory response than seasonal H1N1 influenza virus in ferrets. Arch Virol 156: 759-767.

110. Blackwell TS, Christman JW (1997) The role of nuclear factor-kappa B in cytokine gene regulation. Am J Respir Cell Mol Biol 17: 3-9.
111. Mogensen TH, Paludan SR (2001) Molecular pathways in virus-induced cytokine production. Microbiol Mol Biol Rev 65: 131-150.

112. Hiscott J, Kwon H, Génin P (2001) Hostile takeovers: viral appropriation of the NF-kappaB pathway. J Clin Invest 107: 143-151.

113. Kumar N, Xin ZT, Liang Y, Ly H, Liang $Y$ (2008) NF-kappaB signaling differentially regulates influenza virus RNA synthesis. J Virol 82: 9880-9889.

114. Ludwig S, Pleschka S, Planz O, Wolff T (2006) Ringing the alarm bells: signalling and apoptosis in influenza virus infected cells. Cell Microbiol 8: 375-386.

115. Wurzer WJ, Planz O, Ehrhardt C, Giner M, Silberzahn T, et al. (2003) Caspase 3 activation is essential for efficient influenza virus propagation. EMBO J 22 2717-2728.

116. Wurzer WJ, Ehrhardt C, Pleschka S, Berberich-Siebelt F, Wolff T, et al. (2004) NF-kappaB-dependent induction of tumor necrosis factor-related apoptosisinducing ligand (TRAIL) and Fas/FasL is crucial for efficient influenza virus propagation. J Biol Chem 279: 30931-30937.

117. Roberson EC, Tully JE, Guala AS, Reiss JN, Godburn KE, et al. (2012) Influenza induces endoplasmic reticulum stress, caspase-12-dependen apoptosis, and c-Jun N-terminal kinase-mediated transforming growth factor- $\beta$ release in lung epithelial cells. Am J Respir Cell Mol Biol 46: 573-581.

118. Droebner K, Reiling SJ, Planz O (2008) Role of hypercytokinemia in NFkappaB p50-deficient mice after H5N1 influenza A virus infection. J Virol 82 $11461-11466$

119. Knobil K, Choi AM, Weigand GW, Jacoby DB (1998) Role of oxidants in influenza virus-induced gene expression. Am J Physiol 274: L134-142.

120.Brydon EW, Morris SJ, Sweet C (2005) Role of apoptosis and cytokines in influenza virus morbidity. FEMS Microbiol Rev 29: 837-850.

121. Deng R, Lu M, Korteweg C, Gao Z, McNutt MA, et al. (2008) Distinctly different expression of cytokines and chemokines in the lungs of two H5N1 avian influenza patients. J Pathol 216: 328-336.

122. Nimmerjahn F, Dudziak D, Dirmeier U, Hobom G, Riedel A, et al. (2004) Active NF-kappaB signalling is a prerequisite for influenza virus infection. J Gen Viro 85: 2347-2356.

123. Bernasconi D, Amici C, La Frazia S, lanaro A, Santoro MG (2005) The IkappaB kinase is a key factor in triggering influenza $A$ virus-induced inflammatory cytokine production in airway epithelial cells. J Biol Chem 280: 24127-24134.

124. Schmolke M, Viemann D, Roth J, Ludwig S (2009) Essential impact of NFkappaB signaling on the $\mathrm{H} 5 \mathrm{~N} 1$ influenza $\mathrm{A}$ virus-induced transcriptome. J Immunol 183: 5180-5189.

125. Pahl HL, Baeuerle PA (1995) Expression of influenza virus hemagglutinin activates transcription factor NF-kappa B. J Virol 69: 1480-1484.

126. Majde JA (2000) Viral double-stranded RNA, cytokines, and the flu. J Interferon Cytokine Res 20: 259-272

127.Pahl HL, Baeuerle PA (1997) The ER-overload response: activation of NFkappa B. Trends Biochem Sci 22: 63-67.

128. Nencioni L, Sgarbanti R, De Chiara G, Garaci E, Palamara AT (2007) Influenza virus and redox mediated cell signaling: a complex network of virus/ host interaction. New Microbiol 30: 367-375.

129. Flory E, Kunz M, Scheller C, Jassoy C, Stauber R, et al. (2000) Influenza virus-induced NF-kappaB-dependent gene expression is mediated by overexpression of viral proteins and involves oxidative radicals and activation of IkappaB kinase. J Biol Chem 275: 8307-8314.

130.Pahl HL, Baeuerle PA (1996) Activation of NF-kappa B by ER stress requires both $\mathrm{Ca} 2+$ and reactive oxygen intermediates as messengers. FEBS Lett 392 129-136.

131. Nencioni L, luvara A, Aquilano K, Ciriolo MR, Cozzolino F, et al. (2003) Influenza A virus replication is dependent on an antioxidant pathway that involves GSH and Bcl-2. FASEB J 17: 758-760.

132. Huang Y, Zaas AK, Rao A, Dobigeon N, Woolf PJ, et al. (2011) Temporal dynamics of host molecular responses differentiate symptomatic and asymptomatic influenza a infection. PLoS Genet 7: e1002234.

133. Pahl HL (1999) Signal transduction from the endoplasmic reticulum to the cell nucleus. Physiol Rev 79: 683-701.

134. Matsumoto M, Seya T (2008) TLR3: interferon induction by double-stranded RNA including poly(I:C). Adv Drug Deliv Rev 60: 805-812. 
Citation: Lai KY, Wing Yiu George NG, Cheng FF (2015)The W-Shaped Mortality-Age Distribution of Novel H1N1 Influenza Virus Helps Reconstruct the Second Wave of Pandemic 1918 Spanish Flu. J Pulm Respir Med 5: 245. doi:10.4172/2161-105X.1000245

Page 13 of 17

135. Le Goffic R, Pothlichet J, Vitour D, Fujita T, Meurs E, et al. (2007) Cutting Edge: Influenza A virus activates TLR3-dependent inflammatory and RIG-Idependent antiviral responses in human lung epithelial cells. J Immunol 178 3368-3372.

136. Le Goffic R, Balloy V, Lagranderie M, Alexopoulou L, Escriou N, et al. (2006) Detrimental contribution of the Toll-like receptor (TLR)3 to influenza A virusinduced acute pneumonia. PLoS Pathog 2: e53

137. Majde JA, Guha-Thakurta N, Chen Z, Bredow S, Krueger JM (1998) Spontaneous release of stable viral double-stranded RNA into the extracellular medium by influenza virus-infected MDCK epithelial cells: implications for the viral acute phase response. Arch Virol 143: 2371-2380.

138.Ludwig S, Planz O, Pleschka S, Wolff T (2003) Influenza-virus-induced signaling cascades: targets for antiviral therapy? Trends Mol Med 9: 46-52.

139. Koarai A, Sugiura H, Yanagisawa S, Ichikawa T, Minakata $Y$, et al. (2010) Oxidative stress enhances toll-like receptor 3 response to double-stranded RNA in airway epithelial cells. Am J Respir Cell Mol Biol 42: 651-660.

140. Jin B, Sun T, Yu XH, Liu CQ, Yang YX, et al. (2010) Immunomodulatory effects of dsRNA and its potential as vaccine adjuvant. J Biomed Biotechnol 2010: 690438

141. Iwasaki A, Pillai PS (2014) Innate immunity to influenza virus infection. Na Rev Immunol 14: 315-328.

142. Yamaya M, Nadine LK, Ota C, Kubo H, Makiguchi T, et al. (2014) Magnitude of influenza virus replication and cell damage is associated with interleukin-6 production in primary cultures of human tracheal epithelium. Respir Physio Neurobiol 202: 16-23.

143. Meduri GU, Kohler G, Headley S, Tolley E, Stentz F, et al. (1995) Inflammatory cytokines in the BAL of patients with ARDS. Persistent elevation over time predicts poor outcome. Chest 108: 1303-1314.

144. Muñoz C, Pascual-Salcedo D, Castellanos MC, Alfranca A, Aragonés J, et al. (1996) Pyrrolidine dithiocarbamate inhibits the production of interleukin-6, interleukin-8, and granulocyte-macrophage colony-stimulating factor by human endothelial cells in response to inflammatory mediators: modulation of NF-kappa B and AP-1 transcription factors activity. Blood 88: 3482-3490.

145. Uchide N, Ohyama K, Toyoda H (2010) Current and Future Anti-Influenza Virus Drugs The Open Antimicrobial Agents Journal 2: 34-48

146. Ye S, Lowther S, Stambas J (2015) Inhibition of Reactive Oxygen Species Production Ameliorates Inflammation Induced by Influenza A Viruses via Upregulation of SOCS1 and SOCS3. J Virol 89: 2672-2683.

147.Allen IC, Scull MA, Moore CB, Holl EK, McElvania-TeKippe E, et al. (2009) The NLRP3 inflammasome mediates in vivo innate immunity to influenza A virus through recognition of viral RNA. Immunity 30: 556-565.

148. Ichinohe T, Lee HK, Ogura Y, Flavell R, Iwasaki A (2009) Inflammasome recognition of influenza virus is essential for adaptive immune responses. $J$ Exp Med 206: 79-87.

149.Pang IK, Iwasaki A (2011) Inflammasomes as mediators of immunity against influenza virus. Trends Immunol 32: 34-41.

150. Blchinohe T, Pang IK, Kumamoto Y, Peaper DR, Ho JH, et al. (2011) Microbiota regulates immune defense against respiratory tract influenza $A$ virus infection. Proc Natl Acad Sci USA 108: 5354-5359.

151. Jin C, Flavell RA (2010) Molecular mechanism of NLRP3 inflammasome activation. J Clin Immunol 30: 628-631.

152. Osawa R, Williams KL, Singh N (2011) The inflammasome regulatory pathway and infections: role in pathophysiology and clinical implications. J Infect 62 119-129.

153. Barker BR, Taxman DJ, Ting JP (2011) Cross-regulation between the IL-1 $\left.\right|^{2}$ IL-18 processing inflammasome and other inflammatory cytokines. Curr Opin Immunol 23: 591-597.

154. Ichinohe T, Pang IK, Iwasaki A (2010) Influenza virus activates inflammasomes via its intracellular M2 ion channel. Nat Immunol 11: 404-410.

155. Robb NC, Fodor E (2012) The accumulation of influenza A virus segment 7 spliced mRNAs is regulated by the NS1 protein. J Gen Virol 93: 113-118.

156. Enami K, Sato TA, Nakada S, Enami M (1994) Influenza virus NS1 protein stimulates translation of the M1 protein. J Virol 68: 1432-1437.

157. de la Luna S, Fortes P, Beloso A, Ortín J (1995) Influenza virus NS1 protein enhances the rate of translation initiation of viral mRNAs. J Virol 69: 2427-2433.

158. Garaigorta U, Ortín J (2007) Mutation analysis of a recombinant NS replicon shows that influenza virus NS1 protein blocks the splicing and nucleocytoplasmic transport of its own viral mRNA. Nucleic Acids Res 35: 4573-4582.

159. Stasakova J, Ferko B, Kittel C, Sereinig S, Romanova J, et al. (2005) Influenza A mutant viruses with altered NS1 protein function provoke caspase-1 activation in primary human macrophages, resulting in fast apoptosis and release of high levels of interleukins 1 beta and 18. J Gen Virol 86: 185-195.

160. Ichinohe T, Lee HK, Ogura Y, Flavell R, Iwasaki A (2009) Inflammasome recognition of influenza virus is essential for adaptive immune responses. J Exp Med 206: 79-87.

161. Hennet T, Ziltener HJ, Frei K, Peterhans E (1992) A kinetic study of immune mediators in the lungs of mice infected with influenza A virus. J Immunol 149 : 932-939.

162. Julkunen I, Sareneva T, Pirhonen J, Ronni T, Melén K, et al. (2001) Molecula pathogenesis of influenza A virus infection and virus-induced regulation of cytokine gene expression. Cytokine Growth Factor Rev 12: 171-180.

163. Pirhonen J, Sareneva T, Kurimoto M, Julkunen I, Matikainen S (1999) Virus infection activates IL-1 beta and IL-18 production in human macrophages by a caspase-1-dependent pathway. J Immunol 162: 7322-7329.

164. Sareneva T, Matikainen S, Kurimoto M, Julkunen I (1998) Influenza A virusinduced IFN-alpha/beta and IL-18 synergistically enhance IFN-gamma gene expression in human T cells. J Immunol 160: 6032-6038.

165. Chiaretti A, Pulitanò S, Barone G, Ferrara P, Romano V, et al. (2013) IL-1 $\hat{I}^{2}$ and IL-6 upregulation in children with $\mathrm{H} 1 \mathrm{~N} 1$ influenza virus infection. Mediators Inflamm 2013: 495848.

166. Vongsakul M, Kasisith J, Noisumdaeng P, Puthavathana P (2011) The difference in IL -1beta, MIP-1alpha, IL-8 and IL-18 production between the infection of PMA activated U937 cells with recombinant vaccinia viruses inserted 2004 H5N1 influenza HA genes and NS genes. Asian Pac J Allergy Immunol 29: 349-356.

167. Rintahaka J, Wiik D, Kovanen PE, Alenius H, Matikainen S (2008) Cytosolic antiviral RNA recognition pathway activates caspases 1 and 3 . J Immunol 180: 1749-1757.

168. Kanneganti TD, Body-Malapel M, Amer A, Park JH, Whitfield J, et al. (2006) Critical role for Cryopyrin/Nalp3 in activation of caspase-1 in response to vira infection and double-stranded RNA. J Biol Chem 281: 36560-36568.

169. Thomas PG, Dash P, Aldridge JR Jr, Ellebedy AH, Reynolds C, et al. (2009) The intracellular sensor NLRP3 mediates key innate and healing responses to influenza A virus via the regulation of caspase-1. Immunity 30: 566-575.

170.Tschopp J, Schroder K (2010) NLRP3 inflammasome activation: The convergence of multiple signalling pathways on ROS production? Nat Rev Immunol 10: 210-215.

171. Gram AM, Frenkel J, Ressing ME (2012) Inflammasomes and viruses: cellular defence versus viral offence. J Gen Virol 93: 2063-2075.

172.Zhou R, Tardivel A, Thorens B, Choi I, Tschopp J (2010) Thioredoxininteracting protein links oxidative stress to inflammasome activation. Nat Immunol 11: 136-140.

173. Pang IK, Iwasaki A (2011) Inflammasomes as mediators of immunity against influenza virus. Trends Immunol 32: 34-41.

174.Dolinay T, Kim YS, Howrylak J, Hunninghake GM, An CH, et al. (2012) Inflammasome-regulated cytokines are critical mediators of acute lung injury. Am J Respir Crit Care Med 185: 1225-1234.

175.Liu JQ, He ZJ, Lin HY, Yao YM, Sheng ZY (2004) [Dynamic change in interleukin-18 and its relationships with multiple organ dysfunction syndrome] Zhongguo Wei Zhong Bing Ji Jiu Yi Xue 16: 70-72.

176. Takada H, Ohga S, Mizuno Y, Suminoe A, Matsuzaki A, et al. (1999) Oversecretion of IL-18 in haemophagocytic lymphohistiocytosis: a novel marker of disease activity. Br J Haematol 106: 182-189.

177. Mazodier K, Marin V, Novick D, Farnarier C, Robitail S, et al. (2005) Severe imbalance of IL-18/IL-18BP in patients with secondary hemophagocytic syndrome. Blood 106: 3483-3489.

178. Hsieh YC, Wu TZ, Liu DP, Shao PL, Chang LY, et al. (2006) Influenza pandemics: past, present and future. J Formos Med Assoc 105: 1-6.

179.Zheng Y, Yang Y, Zhao W, Wang H (2010) Novel swine-origin influenza A 
(H1N1) virus-associated hemophagocytic syndrome--a first case report. Am J Trop Med Hyg 82: 743-745.

180. Asai N, Ohkuni Y, Matsunuma R, Iwama K, Otsuka Y, et al. (2012) A case of novel swine influenza A (H1N1) pneumonia complicated with virus-associated hemophagocytic syndrome. J Infect Chemother 18: 771-774.

181.Soto-Abraham MV, Soriano-Rosas J, Díaz-Quiñónez A, Silva-Pereyra J Vazquez-Hernandez P, et al. (2009) Pathological changes associated with the 2009 H1N1 virus. N Engl J Med 361: 2001-2003.

182. Willekens C, Cornelius A, Guerry MJ, Wacrenier A, Fourrier F (2011) Fulminant hemophagocytic lymphohistiocytosis induced by pandemic $A$ (H1N1) influenza: a case report. J Med Case Rep 5: 280.

183. Beutel G, Wiesner O, Eder M, Hafer C, Schneider AS, et al. (2011) Virusassociated hemophagocytic syndrome as a major contributor to death in patients with 2009 influenza A (H1N1) infection. Crit Care 15: R80.

184. Peltola VT, Boyd KL, McAuley JL, Rehg JE, McCullers JA (2006) Bacteria sinusitis and otitis media following influenza virus infection in ferrets. Infect Immun 74: 2562-2567.

185. Huang SS, Banner D, Fang Y, Ng DC, Kanagasabai T, et al. (2011) Comparative analyses of pandemic $\mathrm{H} 1 \mathrm{~N} 1$ and seasonal $\mathrm{H} 1 \mathrm{~N} 1, \mathrm{H} 3 \mathrm{~N} 2$, and influenza B infections depict distinct clinical pictures in ferrets. PLoS One 6: e27512.

186. Rosen DG, Lopez AE, Anzalone ML, Wolf DA, Derrick SM, et al. (2010) Postmortem findings in eight cases of influenza A/H1N1. Mod Pathol 23: 1449-1457.

187. Harms PW, Schmidt LA, Smith LB, Newton DW, Pletneva MA, et al. (2010) Autopsy findings in eight patients with fatal H1N1 influenza. Am J Clin Patho $134: 27-35$

188. Nelson GE, Gershman KA, Swerdlow DL, Beall BW, Moore MR (2012) Invasive pneumococcal disease and pandemic (H1N1) 2009, Denver, Colorado, USA. Emerg Infect Dis 18: 208-216.

189. Taubenberger JK, Morens DM (2008) The pathology of influenza virus infections. Annu Rev Pathol 3: 499-522.

190. World Health Organization Recommendation for The Use of Influenza Vaccine.

191. Morens DM, Taubenberger JK, Fauci AS (2008) Predominant role of bacterial pneumonia as a cause of death in pandemic influenza: implications for pandemic influenza preparedness. J Infect Dis 198: 962-970.

192. Karlström A, Boyd KL, English BK, McCullers JA (2009) Treatment with protein synthesis inhibitors improves outcomes of secondary bacterial pneumonia after influenza. J Infect Dis 199: 311-319.

193. Davis BM, Aiello AE, Dawid S, Rohani P, Shrestha S, et al. (2012) Influenza and community-acquired pneumonia interactions: the impact of order and time of infection on population patterns. Am J Epidemiol 175: 363-367.

194.Palacios G, Hornig M, Cisterna D, Savji N, Bussetti AV, et al. (2009) Streptococcus pneumoniae coinfection is correlated with the severity of $\mathrm{H} 1 \mathrm{~N} 1$ pandemic influenza. PLoS One 4: e8540.

195. Centers for Disease Control and Prevention (CDC) (2009) Bacterial coinfections in lung tissue specimens from fatal cases of 2009 pandemic influenza A (H1N1) - United States, May-August 2009. MMWR Morb Mortal Wkly Rep 58: 1071-1074.

196. Short KR, Habets MN, Hermans PW, Diavatopoulos DA (2012) Interactions between Streptococcus pneumoniae and influenza virus: a mutually beneficial relationship? Future Microbiol 7: 609-624.

197. McCullers JA (2014) The co-pathogenesis of influenza viruses with bacteria in the lung. Nat Rev Microbiol 12: 252-262.

198. McCullers JA, Bartmess KC (2003) Role of neuraminidase in lethal synergism between influenza virus and Streptococcus pneumoniae. J Infect Dis 187: 1000-1009.

199. Peltola VT, Murti KG, McCullers JA (2005) Influenza virus neuraminidase contributes to secondary bacterial pneumonia. J Infect Dis 192: 249-257.

200. McCullers JA (2006) Insights into the interaction between influenza virus and pneumococcus. Clin Microbiol Rev 19: 571-582.

201. Kash JC, Walters KA, Davis AS, Sandouk A, Schwartzman LM, et al. (2011) Lethal synergism of 2009 pandemic H1N1 influenza virus and Streptococcus pneumoniae coinfection is associated with loss of murine lung repair responses. MBio 2.
202. Ballinger MN, Standiford TJ (2010) Postinfluenza bacterial pneumonia: host defenses gone awry. J Interferon Cytokine Res 30: 643-652.

203. Ghoneim HE, Thomas PG, McCullers JA (2013) Depletion of alveolar macrophages during influenza infection facilitates bacterial superinfections. $J$ Immunol 191: 1250-1259.

204. Scheiblauer H, Reinacher M, Tashiro M, Rott R (1992) Interactions between bacteria and influenza $A$ virus in the development of influenza pneumonia. $J$ Infect Dis 166: 783-791.

205. Garten W, Klenk H (2008) Cleavage activation of the influenza virus hemagglutinin and its role in pathogenesis avian influenza. Monogr Virol 27 156-167

206. Nagatake T (2003) [Potentiation of infectivity and pathogenesis of influenza virus by host and bacterial proteases]. Nihon Rinsho 61: 1892-1896.

207. Mancini DA, Alves RC, Mendonça RM, Bellei NJ, Carraro E, et al. (2008) Influenza virus and proteolytic bacteria co-infection in respiratory tract from individuals presenting respiratory manifestations. Rev Inst Med Trop Sao Paulo 50: 41-46.

208. Alicino C, ludici R, Alberti M, Durando P (2011) The dangerous synergism between influenza and Streptococcus pneumoniae and innovative perspectives of vaccine prevention. J Prev Med Hyg 52: 102-106.

209. Gupta RK, George R, Nguyen-Van-Tam JS (2008) Bacterial pneumonia and pandemic influenza planning. Emerg Infect Dis 14: 1187-1192.

210. Weinberger DM, Simonsen L, Jordan R, Steiner C, Miller M, et al. (2012) Impac of the 2009 influenza pandemic on pneumococcal pneumonia hospitalizations in the United States. J Infect Dis 205: 458-465.

211. Grigg J, Walters H, Sohal SS, Wood-Baker R, Reid DW, et al. (2012) Cigarette smoke and platelet-activating factor receptor dependent adhesion of Streptococcus pneumoniae to lower airway cells. Thorax 67: 908-913.

212. Cundell DR, Gerard C, Idanpaan-Heikkila I, Tuomanen EI, Gerard NP (1996) PAf receptor anchors Streptococcus pneumoniae to activated human endothelial cells. Adv Exp Med Biol 416: 89-94.

213. Cundell DR, Gerard NP, Gerard C, Idanpaan-Heikkila I, Tuomanen EI (1995) Streptococcus pneumoniae anchor to activated human cells by the receptor for platelet-activating factor. Nature 377: 435-438.

214. Noah TL, Zhou H, Jaspers I (2012) Alteration of the nasal responses to influenza virus by tobacco smoke. Curr Opin Allergy Clin Immunol 12: 24-31.

215. Noah TL, Zhou H, Monaco J, Horvath K, Herbst M, et al. (2011) Tobacco smoke exposure and altered nasal responses to live attenuated influenza virus. Environ Health Perspect 119: 78-83.

216. Horvath KM, Herbst M, Zhou H, Zhang H, Noah TL, et al. (2011) Nasal lavage natural killer cell function is suppressed in smokers after live attenuated influenza virus. Respir Res 12: 102.

217. Horvath KM, Brighton LE, Herbst M, Noah TL, Jaspers I (2012) Live attenuated influenza virus (LAIV) induces different mucosal T cell function in nonsmokers and smokers. Clin Immunol 142: 232-236.

218. Nuorti JP, Butler JC, Farley MM, Harrison LH, McGeer A, et al. (2000) Cigarette smoking and invasive pneumococcal disease. Active Bacterial Core Surveillance Team. N Engl J Med 342: 681-689.

219. Wong CM, Yang L, Chan KP, Chan WM, Song L, et al. (2013) Cigarette smoking as a risk factor for influenza-associated mortality: evidence from an elderly cohort. Influenza Other Respir Viruses 7: 531-539.

220.Gu D, Kelly TN, Wu X, Chen J, Samet JM, et al. (2009) Mortality attributable to smoking in China. N Engl J Med 360: 150-159.

221.Zhang J, Ou JX, Bai CX (2011) Tobacco smoking in China: prevalence, disease burden, challenges and future strategies. Respirology 16: 1165-1172.

222. Basler CF, Aguilar PV (2008) Progress in identifying virulence determinants of the $1918 \mathrm{H} 1 \mathrm{~N} 1$ and the Southeast Asian H5N1 influenza A viruses. Antiviral Res 79: 166-178.

223. Mok KP, Wong CH, Cheung CY, Chan MC, Lee SM, et al. (2009) Vira genetic determinants of $\mathrm{H} 5 \mathrm{~N} 1$ influenza viruses that contribute to cytokine dysregulation. J Infect Dis 200: 1104-1112.

224.Zhou J, Wang D, Gao R, Zhao B, Song J, et al. (2013) Biological features of novel avian influenza A (H7N9) virus. Nature 499: 500-503.

225. Yu L, Wang Z, Chen Y, Ding W, Jia H, et al. (2013) Clinical, virological, and 
Citation: Lai KY, Wing Yiu George NG, Cheng FF (2015)The W-Shaped Mortality-Age Distribution of Novel H1N1 Influenza Virus Helps Reconstruct the Second Wave of Pandemic 1918 Spanish Flu. J Pulm Respir Med 5: 245. doi:10.4172/2161-105X.1000245

Page 15 of 17

histopathological manifestations of fatal human infections by avian influenza A(H7N9) virus. Clin Infect Dis 57: 1449-1457.

226. Wang Z, Zhang A, Wan Y, Liu X, Qiu C, et al. (2014) Early hypercytokinemia is associated with interferon-induced transmembrane protein-3 dysfunction and predictive of fatal H7N9 infection. Proc Natl Acad Sci U S A 111: 769-774.

227. Han K, Ma H, An X, Su Y, Chen J, et al. (2011) Early use of glucocorticoids was a risk factor for critical disease and death from $\mathrm{pH} 1 \mathrm{~N} 1$ infection. Clin Infect Dis 53: 326-333.

228. Brun-Buisson C, Richard JC, Mercat A, Thiébaut AC, Brochard L; REVASRLF A/H1N1v 2009 Registry Group (2011) Early corticosteroids in severe influenza $\mathrm{A} / \mathrm{H} 1 \mathrm{~N} 1$ pneumonia and acute respiratory distress syndrome. Am J Respir Crit Care Med 183: 1200-1206.

229. Hu Y, Lu S, Song Z, Wang W, Hao P, et al. (2013) Association between adverse clinical outcome in human disease caused by novel influenza A H7N9 virus and sustained viral shedding and emergence of antiviral resistance. Lancet 381: 2273-2279.

230.Wong SS, Yuen KY (2008) Avian influenza A/H5N1 virus: management in human and bird. Hong Kong Med J 14: 252-254.

231.Xu T, Qiao J, Zhao L, He G, Li K, et al. (2009) Effect of dexamethasone on acute respiratory distress syndrome induced by the H5N1 virus in mice. Eur Respir J 33: 852-860.

232. Darwish I, Mubareka S, Liles WC (2011) Immunomodulatory therapy for severe influenza. Expert Rev Anti Infect Ther 9: 807-822.

233. Hui DS, Lee N, Chan PK (2013) Adjunctive therapies and immunomodulatory agents in the management of severe influenza. Antiviral Res 98: 410-416.

234. Fedson DS (2013) Treating influenza with statins and other immunomodulatory agents. Antiviral Res 99: 417-435.

235. Owen DM, Gale M Jr (2009) Fighting the flu with inflammasome signaling. Immunity 30: 476-478.

236. Pinto R, Herold S, Cakarova L, Hoegner K, Lohmeyer J, et al. (2011) Inhibition of influenza virus-induced NF-kappaB and Raf/MEK/ERK activation can reduce both virus titers and cytokine expression simultaneously in vitro and in vivo. Antiviral Res 92: 45-56.

237. Haasbach E, Pauli EK, Spranger R, Mitzner D, Schubert U, et al. (2011) Antiviral activity of the proteasome inhibitor VL-01 against influenza $A$ viruses. Antiviral Res 91: 304-313.

238. Widjaja I, de Vries E, Tscherne DM, García-Sastre A, Rottier PJ, et al. (2010) Inhibition of the ubiquitin-proteasome system affects influenza A virus infection at a postfusion step. J Virol 84: 9625-9631.

239. Wiesener N, Zimmer C, Jarasch-Althof N, Wutzler P, Henke A (2011) Therapy of experimental influenza virus infection with pyrrolidine dithiocarbamate. Med Microbiol Immunol 200: 115-126.

240. Uchide N, Ohyama K (2003) Antiviral function of pyrrolidine dithiocarbamate against influenza virus: the inhibition of viral gene replication and transcription. J Antimicrob Chemother 52: 8-10.

241. Akaike T, Ando M, Oda T, Doi T, ljiri S, et al. (1990) Dependence on O2generation by xanthine oxidase of pathogenesis of influenza virus infection in mice. J Clin Invest 85: 739-745.

242. Snelgrove RJ, Edwards L, Rae AJ, Hussell T (2006) An absence of reactive oxygen species improves the resolution of lung influenza infection. Eur $J$ Immunol 36: 1364-1373.

243. Uchide N, Toyoda H (2011) Antioxidant therapy as a potential approach to severe influenza-associated complications. Molecules 16: 2032-2052.

244. Thomas PG, Dash P, Aldridge JR Jr, Ellebedy AH, Reynolds C et al. (2009) The intracellular sensor NLRP3 (NALP3/CIAS1/Cryopyrin) mediates key innate and healing responses to influenza A virus via the regulation of caspase- 1 . Immunity 30: 566-575

245.Pétrilli V, Dostert C, Muruve DA, Tschopp J (2007) The inflammasome: danger sensing complex triggering innate immunity. Curr Opin Immunol 19 : 615-622.

246. Geiler J, Michaelis M, Naczk P, Leutz A, Langer K, et al. (2010) N-acetyl-Lcysteine (NAC) inhibits virus replication and expression of pro-inflammatory molecules in A549 cells infected with highly pathogenic H5N1 influenza A virus. Biochem Pharmacol 79: 413-420.

247. Ungheri D, Pisani C, Sanson G, Bertani A, Schioppacassi G, et al. (2000)
Protective effect of $n$-acetylcysteine in a model of influenza infection in mice. Int J Immunopathol Pharmacol 13: 123-128.

248. Ghezzi P, Ungheri D (2004) Synergistic combination of $\mathrm{N}$-acetylcysteine and ribavirin to protect from lethal influenza viral infection in a mouse model. Int $\mathrm{J}$ Immunopathol Pharmacol 17: 99-102.

249. Garozzo A, Tempera G, Ungheri D, Timpanaro R, Castro A (2007) $\mathrm{N}$-acetylcysteine synergizes with oseltamivir in protecting mice from lethal influenza infection. Int J Immunopathol Pharmacol 20: 349-354.

250.Lai KY, Ng WY, Osburga Chan PK, Wong KF, Cheng F (2010) High-dose $\mathrm{N}$-acetylcysteine therapy for novel H1N1 influenza pneumonia. Ann Intern Med 152: 687-688.

251. Prescott LF, Donovan JW, Jarvie DR, Proudfoot AT (1989) The disposition and kinetics of intravenous $\mathrm{N}$-acetylcysteine in patients with paracetamo overdosage. Eur J Clin Pharmacol 37: 501-506.

252. Garigliany MM, Desmecht DJ (2011) N-acetylcysteine lacks universa inhibitory activity against influenza A viruses. J Negat Results Biomed 10: 5.

253.Boon AC, Vos AP, Graus YM, Rimmelzwaan GF, Osterhaus AD (2002) In vitro effect of bioactive compounds on influenza virus specific B- and T-cell responses. Scand J Immunol 55: 24-32.

254.De Flora S, Grassi C, Carati L (1997) Attenuation of influenza-like symptomatology and improvement of cell-mediated immunity with long-term $\mathrm{N}$-acetylcysteine treatment. Eur Respir J 10: 1535-1541.

255. Borgström L, Kågedal B, Paulsen O (1986) Pharmacokinetics of $\mathrm{N}$-acetylcysteine in man. Eur J Clin Pharmacol 31: 217-222.

256. De Flora S, Izzotti A, D’Agostini F, Balansky RM (2001) Mechanisms of $\mathrm{N}$-acetylcysteine in the prevention of DNA damage and cancer, with special reference to smoking-related end-points. Carcinogenesis 22: 999-1013.

257. McElhatton PR, Sullivan FM, Volans GN (1997) Paracetamol overdose in pregnancy analysis of the outcomes of 300 cases referred to the Teratology Information Service. Reprod Toxicol 11: 85-94.

258. Kozer E, Koren G (2001) Management of paracetamol overdose: current controversies. Drug Saf 24: 503-512.

259. Youn HS, Lim HJ, Choi YJ, Lee JY, Lee MY, et al. (2008) Selenium suppresses the activation of transcription factor NF-kappa B and IRF3 induced by TLR3 or TLR4 agonists. Int Immunopharmacol 8: 495-501.

260. Nelson HK, Shi Q, Van Dael P, Schiffrin EJ, Blum S, et al. (2001) Host nutritional selenium status as a driving force for influenza virus mutations. FASEB J 15: 1846-1848.

261.Beck MA, Nelson HK, Shi Q, Van Dael P, Schiffrin EJ, et al. (2001) Selenium deficiency increases the pathology of an influenza virus infection. FASEB $\mathrm{J}$ 15: $1481-1483$

262. Jaspers I, Zhang W, Brighton LE, Carson JL, Styblo M, et al. (2007) Selenium deficiency alters epithelial cell morphology and responses to influenza. Free Radic Biol Med 42: 1826-1837.

263. Yu L, Sun L, Nan Y, Zhu LY (2011) Protection from H1N1 influenza virus infections in mice by supplementation with selenium: a comparison with selenium-deficient mice. Biol Trace Elem Res 141: 254-261.

264. Wang L, Hou Y (2011) Determination of trace elements in anti-influenza virus mushrooms. Biol Trace Elem Res 143: 1799-1807.

265. Yu M, Liu X, Cao S, Zhao Z, Zhang K, et al. (2012) Identification and characterization of three novel nuclear export signals in the influenza $A$ virus nucleoprotein. J Virol 86: 4970-4980

266. Mazur I, Wurzer WJ, Ehrhardt C, Pleschka S, Puthavathana P, et al. (2007) Acetylsalicylic acid (ASA) blocks influenza virus propagation via its NFkappaB-inhibiting activity. Cell Microbiol 9: 1683-1694.

267.Lee SM, Gai WW, Cheung TK, Peiris JS (2011) Antiviral effect of a selective COX-2 inhibitor on H5N1 infection in vitro. Antiviral Res 91: 330-334.

268. Kopp E, Ghosh S (1994) Inhibition of NF-kappa B by sodium salicylate and aspirin. Science 265: 956-959.

269. Palombella VJ, Rando OJ, Goldberg AL, Maniatis T (1994) The ubiquitinproteasome pathway is required for processing the NF-kappa B1 precursor protein and the activation of NF-kappa B. Cell 78: 773-785.

270. Porter JD, Robinson PH, Glasgow JF, Banks JH, Hall SM (1990) Trends in 
Citation: Lai KY, Wing Yiu George NG, Cheng FF (2015)The W-Shaped Mortality-Age Distribution of Novel H1N1 Influenza Virus Helps Reconstruct the Second Wave of Pandemic 1918 Spanish Flu. J Pulm Respir Med 5: 245. doi:10.4172/2161-105X.1000245

Page 16 of 17

the incidence of Reye's syndrome and the use of aspirin. Arch Dis Child 65: 826-829.

271. Hui DS, Lee N (2013) Adjunctive therapies and immunomodulating agents for severe influenza. Influenza Other Respir Viruses 7 Suppl 3: 52-59.

272. Lee SM, Gai WW, Cheung TK, Peiris JS (2011) Antiviral effect of a selective COX-2 inhibitor on H5N1 infection in vitro. Antiviral Res 91: 330-334.

273. Woo PC, Tung ET, Chan KH, Lau CC, Lau SK, et al. (2010) Cytokine profiles induced by the novel swine-origin influenza $\mathrm{A} / \mathrm{H} 1 \mathrm{~N} 1$ virus: implications for treatment strategies. J Infect Dis 201: 346-353.

274. Punchard NA, Greenfield SM, Thompson RP (1992) Mechanism of action of 5-arninosalicylic acid. Mediators Inflamm 1: 151-165

275. Lauder SN, Taylor PR, Clark SR, Evans RL, Hindley JP, et al. (2011) Paracetamol reduces influenza-induced immunopathology in a mouse model of infection without compromising virus clearance or the generation of protective immunity. Thorax 66: 368-374

276. Ueda M, Daidoji T, Du A, Yang CS, Ibrahim MS, et al. (2010) Highly pathogenic H5N1 avian influenza virus induces extracellular Ca2+ influx, leading to apoptosis in avian cells. J Virol 84: 3068-3078.

277. Daidoji T, Koma T, Du A, Yang CS, Ueda M, et al. (2008) H5N1 avian influenza virus induces apoptotic cell death in mammalian airway epithelial cells. J Viro 82: 11294-11307.

278. König R, Stertz S, Zhou Y, Inoue A, Hoffmann HH, et al. (2010) Human host factors required for influenza virus replication. Nature 463: 813-817.

279. Govorkova EA, Leneva IA, Goloubeva OG, Bush K, Webster RG (2001) Comparison of efficacies of RWJ-270201, zanamivir, and oseltamivir agains H5N1, H9N2, and other avian influenza viruses. Antimicrob Agents Chemother 45: 2723-2732.

280.Smith JR, Rayner CR, Donner B, Wollenhaupt M, Klumpp K, et al. (2011) Oseltamivir in seasonal, pandemic, and avian influenza: a comprehensive review of 10-years clinical experience. Adv Ther 28: 927-959.

281. Adisasmito W, Chan PK, Lee N, Oner AF, Gasimov V, et al. (2010) Effectiveness of antiviral treatment in human influenza $A(H 5 N 1)$ infections: analysis of a Global Patient Registry. J Infect Dis 202: 1154-1160.

282. Zheng BJ, Chan KW, Lin YP, Zhao GY, Chan C, et al. (2008) Delayed antiviral plus immunomodulator treatment still reduces mortality in mice infected by high inoculum of influenza A/H5N1 virus. Proc Natl Acad Sci U S A 105: 8091-8096.

283. Dávila J, Chowell G, Borja-Aburto VH, Viboud C, Grajales Muñiz C, et al. (2014) Substantial Morbidity and Mortality Associated with Pandemic A/H1N1 Influenza in Mexico, Winter 2013-2014: Gradual Age Shift and Severity. PLoS Curr 6.

284. CDC Health Alert Network (2013) Notice to Clinicians: Early Reports of pH1N1 Associated Illnesses for the 2013-14 Influenza Season CDCHAN-00359

285. Knepper J, Schierhorn KL, Becher A, Budt M, Tönnies M, et al. (2013) The novel human influenza $A(H 7 N 9)$ virus is naturally adapted to efficient growth in human lung tissue. MBio 4: e00601-00613.

286. Basler CF, Aguilar PV (2008) Progress in identifying virulence determinants of the $1918 \mathrm{H} 1 \mathrm{~N} 1$ and the Southeast Asian H5N1 influenza A viruses. Antiviral Res 79: 166-178.

287. Zhou J, Wang D, Gao R, Zhao B, Song J, et al. (2013) Biological features of novel avian influenza A (H7N9) virus. Nature 499: 500-503.

288. Cheung CY, Poon LL, Lau AS, Luk W, Lau YL, et al. (2002) Induction of proinflammatory cytokines in human macrophages by influenza A (H5N1) viruses: a mechanism for the unusual severity of human disease? Lancet 360 1831-1837.

289. Mertz D, Kim TH, Johnstone J, Lam PP, Science M, et al. (2014) Populations at risk for severe or complicated Avian Influenza H5N1: a systematic review and meta-analysis. PLoS One 9: e89697.

290. WHO risk assessment of human infection with avian influenza $A(H 7 N 9)$ virus as off 23rd February 2015.

291. Yuen KY, Chan PK, Peiris M, Tsang DN, Que TL, et al. (1998) Clinical features and rapid viral diagnosis of human disease associated with avian influenza $A$ H5N1 virus. Lancet 351: 467-471.

292. Hsu AC, Parsons K, Barr I, Lowther S, Middleton D, et al. (2012) Critical role of constitutive type I interferon response in bronchial epithelial cell to influenza infection. PLoS One 7: e32947.

293. Kuo RL, Krug RM (2009) Influenza a virus polymerase is an integral component of the CPSF30-NS1A protein complex in infected cells. J Virol 83: 1611-1616.

294. Spesock A, Malur M, Hossain MJ, Chen LM, Njaa BL, et al. (2011) The virulence of $1997 \mathrm{H} 5 \mathrm{~N} 1$ influenza viruses in the mouse model is increased by correcting a defect in their NS1 proteins. J Virol 85: 7048-7058.

295. Das K, Ma LC, Xiao R, Radvansky B, Aramini J, et al. (2008) Structural basis for suppression of a host antiviral response by influenza $A$ virus. Proc Nat Acad Sci U S A 105: 13093-13098.

296. Twu KY, Kuo RL, Marklund J, Krug RM (2007) The H5N1 influenza virus NS genes selected after 1998 enhance virus replication in mammalian cells. J Virol 81: 8112-8121.

297. Cumulative number of confirmed human cases for avian influenza $A(H 5 N 1)$ reported to World Health Organization from 2003 to 3rd March 2015.

298. Guan Y, Shortridge KF, Krauss S, Chin PS, Dyrting KC, et al. (2000) H9N2 influenza viruses possessing $\mathrm{H} 5 \mathrm{~N} 1$-like internal genomes continue to circulate in poultry in southeastern China. J Virol 74: 9372-9380.

299.Zhang P, Tang Y, Liu X, Liu W, Zhang X, et al. (2009) A novel genotype H9N2 influenza virus possessing human H5N1 internal genomes has been circulating in poultry in eastern China since 1998. J Virol 83: 8428-8438.

300. Chin PS, Hoffmann E, Webby R, Webster RG, Guan Y, et al. (2002) Molecula evolution of $\mathrm{H} 6$ influenza viruses from poultry in Southeastern China: prevalence of $\mathrm{H} 6 \mathrm{~N} 1$ influenza viruses possessing seven $\mathrm{A} / \mathrm{Hong} \mathrm{Kong} / 156 / 97$ (H5N1)-like genes in poultry. J Virol 76: 507-516.

301. Hoffmann E, Stech J, Leneva I, Krauss S, Scholtissek C, et al. (2000) Characterization of the influenza $A$ virus gene pool in avian species in southern China: was H6N1 a derivative or a precursor of H5N1? J Virol 74: 6309-6315.

302. Taniguchi T, Takaoka A (2001) A weak signal for strong responses: interferonalpha/beta revisited. Nat Rev Mol Cell Biol 2: 378-386.

303. Sato M, Suemori H, Hata N, Asagiri M, Ogasawara K, et al. (2000) Distinct and essential roles of transcription factors IRF-3 and IRF-7 in response to viruses for IFN-alpha/beta gene induction. Immunity 13: 539-548.

304. Génin P, Vaccaro A, Civas A (2009) The role of differential expression of human interferon--a genes in antiviral immunity. Cytokine Growth Factor Rev 20: 283-295.

305. Yao L, Korteweg C, Hsueh W, Gu J (2008) Avian influenza receptor expression in H5N1-infected and noninfected human tissues. FASEB J 22: 733-740.

306. Nicholls JM, Chan MC, Chan WY, Wong HK, Cheung CY, et al. (2007) Tropism of avian influenza A (H5N1) in the upper and lower respiratory tract. Nat Med 13: 147-149.

307. Ramos I, Fernandez-Sesma A (2012) Cell receptors for influenza a viruses and the innate immune response. Front Microbiol 3: 117

308. Ramos I, Bernal-Rubio D, Durham N, Belicha-Villanueva A, Lowen AC, et al. (2011) Effects of receptor binding specificity of avian influenza virus on the human innate immune response. J Virol 85: 4421-4431.

309. Wang Z, Robb NC, Lenz E, Wolff T, Fodor E, et al. (2010) NS reassortment of an $\mathrm{H} 7$-type highly pathogenic avian influenza virus affects its propagation by altering the regulation of viral RNA production and antiviral host response. Virol 84: 11323-11335.

310.Ma W, Brenner D, Wang Z, Dauber B, Ehrhardt C, et al. (2010) The NS segment of an H5N1 highly pathogenic avian influenza virus (HPAIV) is sufficient to alter replication efficiency, cell tropism, and host range of an $\mathrm{H} 7 \mathrm{~N} 1$ HPAIV. J Virol 84: 2122-2133.

311. Shi JZ, Deng GH, Liu PH Zhou JP, Guan LZ et al. (2013) Isolation and characterization of $\mathrm{H} 7 \mathrm{~N} 9$ viruses from live poultry markets-implication of the source of current H7N9 infection in humans. Chin Sci Bull 58: 1857-1863.

312. Liu D, Shi W, Shi Y, Wang $D$, Xiao $H$, et al. (2013) Origin and diversity of novel avian influenza A H7N9 viruses causing human infection: phylogenetic structural, and coalescent analyses. Lancet 381: 1926-1932.

313. Van Ranst M, Lemey $P$ (2013) Genesis of avian-origin H7N9 influenza A viruses. Lancet 381: 1883-1885.

314.Su C, Chen S, Liu X, Xu J, Huang K, et al. (2013) Genome Sequence of a Novel H10N9 Avian Influenza Virus Isolated from Chickens in a Live Poultry Market in Eastern China. Genome Announc 1. 
Citation: Lai KY, Wing Yiu George NG, Cheng FF (2015)The W-Shaped Mortality-Age Distribution of Novel H1N1 Influenza Virus Helps Reconstruct the Second Wave of Pandemic 1918 Spanish Flu. J Pulm Respir Med 5: 245. doi:10.4172/2161-105X.1000245

Page 17 of 17

315. Cumulative number of confirmed cases of avian influenza $A(H 7 N 9)$ reported to World Health Organization as of 25th October 2013.

316. Knepper J, Schierhorn KL, Becher A, Budt M, Tönnies M, et al. (2013) The novel human influenza $A(H 7 N 9)$ virus is naturally adapted to efficient growth in human lung tissue. MBio 4: e00601-00613.

317. Lai KY, Wing YNG, Wong KF, Hung IFN, Hong JKF et al. (2013) Human H7N9 avian influenza virus infection: a review and pandemic risk assessment. Emerging Microbes \& Infections 2: e48.

318. Soares Magalhães RJ, Zhou X, Jia B, Guo F, Pfeiffer DU, et al. (2012) Live poultry trade in Southern China provinces and HPAIV H5N1 infection in humans and poultry: the role of Chinese New Year festivities. PLoS One 7: e49712.

319. World Health Organization: Avian Influenza H5N1 at the human---animal interface: Update on selected projects.

320. Wiratsudakul A, Paul MC, Bicout DJ, Tiensin T, Triampo W, et al. (2014) Modeling the dynamics of backyard chicken flows in traditional trade networks in Thailand: implications for surveillance and control of avian influenza. Trop Anim Health Prod 46: 845-853.

321. Gilbert M, Slingenbergh J, Xiao X (2008) Climate change and avian influenza. Rev Sci Tech 27: 459-466.

322. Christopoulou I, Roose K, Ibañez LI, Saelens X (2015) Influenza vaccines to control influenza-associated bacterial infection: where do we stand? Expert Rev Vaccines 14: 55-67.

323. Chien YW, Levin BR, Klugman KP (2012) The anticipated severity of a "1918like" influenza pandemic in contemporary populations: the contribution of antibacterial interventions. PLoS One 7: e29219.

324. Tomczyk S, Bennett NM, Stoecker C, Gierke R, Moore MR, et al. (2014) Use of 13-valent pneumococcal conjugate vaccine and 23-valent pneumococcal polysaccharide vaccine among adults aged â\% $¥ 65$ years: recommendations of the Advisory Committee on Immunization Practices (ACIP). MMWR Morb Mortal Wkly Rep 63: 822-825.

325. Wling BJ, Jin L, Lau EH, Liao Q, Wu P, et al. (2013) Comparative epidemiology of human infections with avian influenza A H7N9 and H5N1 viruses in China: a population-based study of laboratory-confirmed cases. Lancet 382: 129-137.

326. World Health Organization Report on the Global Tobacco Epidemic 2013.

327. Fedson DS (2008) Confronting an influenza pandemic with inexpensive generic agents: can it be done? Lancet Infect Dis 8: 571-576.

328. Fleming DM, Durnall H (2012) Ten lessons for the next influenza pandemic-an English perspective: a personal reflection based on community surveillance data. Hum Vaccin Immunother 8: 138-145.

329. Jorgensen P, Wasley A, Mereckiene J, Cotter S, Weber JT, et al. (2013) Unequal access to vaccines in the WHO European Region during the $A(H 1 N 1)$ influenza pandemic in 2009. Vaccine 31: 4060-4062.

330.Pada S, Tambyah PA (2011) Overview/reflections on the $2009 \mathrm{H} 1 \mathrm{~N} 1$ pandemic. Microbes Infect 13: 470-478.

331. Kelso JK, Halder N, Milne GJ (2013) Vaccination strategies for future influenza pandemics: a severity-based cost effectiveness analysis. BMC Infect Dis 13: 81.

332. Fedson DS (2009) Confronting the next influenza pandemic with antiinflammatory and immunomodulatory agents: why they are needed and how they might work. Influenza Other Respir Viruses 3: 129-142.

333. Everitt AR, Clare S, Pertel T, John SP, Wash RS, et al. (2012) IFITM3 restricts the morbidity and mortality associated with influenza. Nature 484: 519-523.

334.Zhang YH, Zhao Y, Li N, Peng YC, Giannoulatou E, et al. (2013) Interferoninduced transmembrane protein-3 genetic variant $\mathrm{rs} 12252-\mathrm{C}$ is associated with severe influenza in Chinese individuals. Nat Commun 4: 1418.

335.Liu SF, Malik AB (2006) NF-kappa B activation as a pathological mechanism of septic shock and inflammation. Am J Physiol Lung Cell Mol Physiol 290: L622-622L645.

336. Takeuchi O, Hoshino K, Kawai T, Sanjo H, Takada H, et al. (1999) Differential roles of TLR2 and TLR4 in recognition of gram-negative and gram-positive bacterial cell wall components. Immunity 11: 443-451.

337. Schnare M, Rollinghoff M, Qureshi S (2006) Toll-like receptors: sentinels of host defence against bacterial infection. Int Arch Allergy Immunol 139: 75-85.

338. Sabroe I, Dower SK, Whyte MK (2005) The role of Toll-like receptors in the regulation of neutrophil migration, activation, and apoptosis. Clin Infect Dis 41 Suppl 7: S421-426. 